\title{
A new species of Colostethus (Anura, Dendrobatidae) from French Guiana with a redescription of Colostethus beebei (Noble, 1923) from its type locality
}

\author{
Philippe J. R. Kok ${ }^{1}$, Ross D. MacCulloch², Philippe Gaucher ${ }^{3}$, Erik H. Poelman ${ }^{4}$, Godfrey
} R. Bourne ${ }^{5}$, Amy Lathrop ${ }^{2}$, and Georges L. Lenglet ${ }^{1}$

1 Department of Vertebrates, Royal Belgian Institute of Natural Sciences, 29 rue Vautier, B-1000 Brussels, Belgium. Emails: Philippe.Kok@naturalsciences.be, Georges.Lenglet@naturalsciences.be.

2 Centre for Biodiversity and Conservation Biology, Royal Ontario Museum, 100 Queen’s Park, Toronto, Ontario M5S 2C6, Canada. E-mails: rossm@rom.on.ca, amyl@rom.on.ca.

${ }^{3}$ Mission pour la création du parc de la Guyane, 81 rue Christophe Colomb, BP 275, 97326 Cayenne cedex, Guyane Française. E-mail: phgaucher@wanadoo.fr.

${ }^{4}$ Laboratory of Entomology, Wageningen University, Postbus 8031, 6700 EH Wageningen, The Netherlands. E-mail: Erik.Poelman@wur.nl.

${ }^{5}$ Department of Biology, University of Missouri-St. Louis, 8001 Natural Bridge Road, St. Louis, MO 63121- 4499, USA, and National Science Foundation, Division of Integrative Organismal Biology, Behavioral Systems Cluster, 4201 Wilson Boulevard, Arlington, VA 22230, USA. E-mail: gbourne@nsf.gov.

\begin{abstract}
A new species of Colostethus (Anura, Dendrobatidae) from French Guiana with a redescription of Colostethus beebei (Noble, 1923) from its type locality. A new species of Colostethus, long mistaken for Colostethus beebei, is described from French Guiana. The new species can be distinguished from congeners by absence of median lingual process, first finger longer than second, third finger not distinctly swollen in males, differences in tadpole morphology, coloration and pattern (e.g. absence of dorsolateral stripe), bioacoustics, and reproductive behavior. A complete redescription of Colostethus beebei plus description of its tadpole and call is provided on the basis of recently collected topotypic specimens. The range of $C$. beebei is restricted to the Kaieteur plateau, Pakaraima Mountains, Guyana.
\end{abstract}

Keywords: Anura, Dendrobatidae, Colostethus granti sp. nov., Colostethus beebei, French Guiana, Guyana, Guiana Shield.

\section{Introduction}

Diversity of the genus Colostethus Cope, 1866 has been underestimated (cf. Caldwell and

Received 30 November 2005.

Accepted 30 May 2006.

Distributed September 2006.
Lima 2003) and several species of Colostethus were recently removed from physiognomically similar species and described as new (e.g. Lima and Caldwell 2001, Morales “2000” [2002], Caldwell and Lima 2003, La Marca et al. 2004). These small dendrobatids have been the subject of several recent detailed studies (e.g. Coloma 1995, La Marca “1996” [1997], Grant and 
Castro 1998, Morales “2000” [2002]). Some nominal Colostethus species still appear to be composed of multiple cryptic species and it is assumed that numerous species remain to be described. The task seems crucial given that evidence of population declines has been established (e.g. Coloma 1995, Young et al. 2001, 2004, La Marca 2004, Lips et al. 2005), and that accurate knowledge of species distribution is essential in guiding conservation efforts, which is decisive in these times of global biodiversity loss.

The taxonomic status and nomenclatural history of Colostethus species in the Guianas (Guyana, Suriname, and French Guiana) are notably complicated. Only three species of Colostethus are confirmed from this region (Frost 2004): Colostethus baeobatrachus Boistel and de Massary, 1999 (French Guiana), Colostethus beebei (Noble, 1923) (Guyana and erroneously in Suriname and French Guiana), and Colostethus degranvillei Lescure, 1975 (French Guiana and Suriname). Records of Colostethus brunneus (Cope, 1887) in the Guianas either apply to one or more undescribed species or are due to confusion with other species (cf. Morales “2000” [2002], La Marca et al. 2004). As stressed by several authors (e.g. Caldwell et al. 2002, La Marca et al. 2004, Kok et al. 2005), the considerable amount of intraspecific variation and interspecific convergence in color pattern within and among species of Colostethus has led to some taxonomic confusion. Species-level identification of preserved specimens can be problematic and species are sometimes barely distinguishable using morphological characters alone ( $c f$. Veiga-Menoncello et al. 2003).

The golden rocket frog, Colostethus beebei, is apparently another misidentified taxon, possibly due to its variability in pattern and coloration (cf. Bourne 2001, Kok et al. 2005), but a more probable explanation lies in the brevity of the original description. Indeed, Noble (1923) first described Colostethus beebei (as Hyloxalus beebei) from a single gravid female specimen collected in 1921 by William Beebe near Kaieteur Falls, Guyana and his description is based on a limited number of morphological characters. The species was considered a synonym of Phyllobates brunneus by Cochran ("1954" [1955]) and Cochran and Goin (1970), but resurrected by Edwards (1974) who placed it in the genus Colostethus.

Lescure (1975) was the first to refer to Colostethus beebei outside Guyana, although these specimens were apparently compared only to Noble's (1923) written description of $C$. beebei, and not to actual specimens of $C$. beebei from Guyana. Several other authors have applied the name to Colostethus occurring in French Guiana and Suriname (see below).

Study of recently collected topotypic specimens of $C$. beebei, and of specimens of the purported C. "beebei” from French Guiana, including comparisons of tadpoles and calls, clearly indicate that the latter is a distinct species and, therefore, that $C$. beebei is restricted to Guyana. After further morphological examination of adult specimens from French Guiana and comparisons with physiognomically similar species of Colostethus, including their tadpoles and calls, when available, it became clear that this misidentified species does not belong to any of the Colostethus species known from the Guiana Shield region [region as defined by Huber and Foster (2003)], nor could it be identified as belonging to any extralimital species.

The purpose of this paper is to describe this new species and provide a detailed redescription of Colostethus beebei to clarify the situation.

\section{Materials and Methods}

We collected eight males, seven females, one juvenile and 22 tadpoles of the new species from several localities in French Guiana; these have been deposited in the herpetological collections of the Institut Royal des Sciences Naturelles de Belgique, Brussels, Belgium (IRSNB), the Muséum National d'Histoire Naturelle, Paris, 
France (MNHN) and the Laboratorio de Biogeografía, Universidad de los Andes, Mérida, Venezuela (ULABG). We collected 19 males, 27 females, seven juveniles and 16 tadpoles of Colostethus beebei from the type locality, Kaieteur Falls in Kaieteur National Park, Guyana (05¹0’ N, 59²9' W, elevation $450 \mathrm{~m}$ ) in June 2004 and June 2005; these were deposited in the herpetological collections of IRSNB, ULABG, and the Royal Ontario Museum, Toronto, Canada (ROM). Museum catalogue numbers of specimens examined are in the Appendix. Specimens were collected according to approved animal use protocols. Adult specimens were fixed in $5 \%$ or $10 \%$ formalin and transferred in $70 \%$ ethanol for permanent storage, whereas larvae were preserved in $10 \%$ formalin. Tissue was removed from some specimens and preserved in 95\% ethanol. Color in life was taken from photographs and field notes. Sex was confirmed by dissection.

We measured preserved specimens to the nearest $0.01 \mathrm{~mm}$ with digital calipers on a dissecting stereomicroscope; following Hayek et al. (2001), we rounded all measurements to one decimal point. Terminology, diagnostic characters, and measurements generally follow Caldwell et al. (2002), with some modifications from Grant and Rodríguez (2001) to facilitate comparison with other Colostethus. The following measurements were recorded: snoutvent length (SVL); head length from corner of mouth to tip of snout (HL); head width at level of angle of jaws (HW); snout length from anterior corner of eye to tip of snout (SL); eye to naris distance from anterior corner of eye to centre of naris (EN); internarial distance (IN); eye length (EL); interorbital distance (IO); diameter of tympanum (TYM); forearm length from proximal edge of palmar tubercle to outer edge of flexed elbow (FAL); hand length from proximal edge of palmar tubercle to tip of Finger III (HAND); width of disc on Finger III (WFD); tibia length from outer edge of flexed knee to heel (TL); foot length from proximal edge of outer metatarsal tubercle to tip of Toe
IV (FL); width of disc on Toe IV (WTD). Webbing formulae follow Savage and Heyer (1967) and Lescure (1975) with modifications suggested by Myers and Duellman (1982) and Savage and Heyer (1997). Although some studies of dendrobatids have described interdigital webbing by enumerating webbed phalanges (Edwards 1974, La Marca “1996” [1997], La Marca et al. 2002), other studies have followed the notation used to describe webbing in other anuran taxa, by enumerating phalanges which are free of webbing (e.g. Lescure 1975, Myers et al. 1991, Coloma 1995, Meinhardt and Parmelee 1996, Caldwell et al. 2002); the latter is followed to facilitate comparison among anurans.

Tadpole stages are those of Gosner (1960); oral disc characters follow Altig and McDiarmid (1999). We measured preserved larvae with digital calipers or ocular micrometers on a dissecting stereomicroscope. The following measurements were recorded: total length (TL); body length (BL); tail length (TAL); body width (BW); body height (BH); head width at level of eyes (HW); tail muscle height at base of tail (TMH); tail muscle width at base of tail (TMW); maximum height of tail (MTH); eyenaris distance (END); naris-snout distance (NSD); internarial distance (IND); interorbital distance (IOD); eye diameter (ED); vent tube length (VTL). One stage-25 tadpole of the new species was critical-point dried and coated with gold following the usual protocol (cf. Echeverría 1997) for scanning electron microscopy (SEM). Observations of oral disc and photomicrograph of labial teeth were made with a Philips XL-30 ESEM scanning electron microscope. Drawings were made under a camera lucida.

Vocalizations of $C$. beebei were recorded on a Sony WM-D3 Stereo cassette recorder at the standard tape speed of $8.15 \mathrm{~cm} / \mathrm{sec}$ through a Sennheiser ME-66 microphone at a distance of 1 $\mathrm{m}$ from frogs. A Macintosh iBook computer with Canary version 1.2.4 software was used to analyze quantitative spectral and temporal characteristics of advertisement vocalizations 
from 10 males at a sampling rate of $22 \mathrm{kHz}$ (Charif et al. 1996). Descriptive statistics were obtained from multiple measurements from each of 10 males of $C$. beebei on lower and upper frequencies $(\mathrm{kHz})$, calls/min, notes/call, intercall interval (sec), and internote interval (ms), using SYSTAT 7.0 statistical package for Windows (Wilkinson 1997).

Vocalizations of the new species were recorded at a distance of $1 \mathrm{~m}$ from frogs using a Sennheiser K6 microphone attached to a DAT Sony TCD-D8 recorder on a Sony PDP-65C tape. A HP Laptop computer with Syrinx version 2.4o software (John Burt, www.syrinxpc.com) was used to analyze quantitative spectral and temporal characteristics of advertisement vocalizations from three males at a sampling rate of 22 $\mathrm{kHz}$ (Charif et al. 1996). Temperature during recordings varied from $22-26^{\circ} \mathrm{C}$. Terminology used for the description of the advertisement calls follows Duellman and Trueb (1986).

The new species was compared with museum specimens or original published descriptions as well as those provided in taxonomic revisions and broader faunal treatments (Jiménez de la Espada 1871, Cope 1887, Noble 1923, Melin 1941, Rivero 1961, Lescure 1975, Rivero et al. 1986, Martins 1989, Meinhardt and Parmelee 1996, La Marca “1996” [1997], Myers and Donnelly 1997, 2001, Kok 2000a, Lima and Caldwell 2001, Caldwell et al. 2002, Morales “2000” [2002], Caldwell and Lima 2003, BarrioAmorós et al. 2004, La Marca et al. 2004).

\section{Species Descriptions}

Colostethus granti sp. nov.

Figures 1 (A, C, E), 2, 3, 4 (A, B, E, F), $5,6,7(\mathrm{~A}, \mathrm{C})$

Colostethus beebei (Noble 1923) (part): Lescure 1975, Lescure 1976, Lescure 1987, Boistel and de Massary 1999, Marty and Gaucher 1999, Kok 2000a, Lescure and Marty 2001, Born and Gaucher 2001a, Born and Gaucher 2001b.
Holotype - IRSNB 1932 (field no. PK 205), an adult male with 18 back-riding tadpoles, collected by Philippe J. R. Kok, 17 June 1998, Montagne Belvédère, $c a .7 \mathrm{~km}$ SE from the village of Saül, French Guiana, $3^{\circ} 37^{\prime}$ N, 53ำ' $\mathrm{W}$, elevation ca. $250 \mathrm{~m}$.

Paratypes - IRSNB 1935, paratopotype, collected by Philippe J. R. Kok, 19 November 1996. IRSNB 1933, paratopotype, collected by Philippe J. R. Kok, 25 November 1996. IRSNB 1934, collected by Philippe J. R. Kok, 27 November 1996, along the trail between the airstrip and the village of Saül, French Guiana. IRSNB 1936, paratopotype, collected by Philippe J. R. Kok, 14 June 1998. MNHN 2005.0266, collected by Philippe Gaucher, 26 August 2003 on layon est, Piton Armontabo, StGeorges, French Guiana. MNHN 2005.0267, collected by Philippe Gaucher, August 2003, Piton Armontabo, St-Georges, French Guiana. MNHN 2005.0268, collected by Philippe Gaucher, 20 April 2004 at camp, Haute Wanapi, Maripasoula, French Guiana. MNHN 2005.0269, collected by Philippe Gaucher, 1 July 2004 at camp, Haut Marwini, Maripasoula, French Guiana. MNHN 2005.0270-71, collected by Philippe Gaucher, 2 July 2004 at camp, Haut Marwini, Maripasoula, French Guiana. MNHN 2005.0272, collected by Philippe Gaucher, 20 February 2005 on Montagne Kotika, Papaïchton, French Guiana. MNHN 2005.027374, collected by Philippe Gaucher, 22 February 2005, on Montagne Kotika, Papaïchton, French Guiana. MNHN 2005.0275, collected by Philippe Gaucher on Chemin des Gros Arbres, Saül, French Guiana. MNHN 2005.0276-77 (4 tadpoles), collected by Philippe Gaucher, 20 February 2005, on Montagne Kotika, Papaïchton, French Guiana. ULABG 6816 (ex IRSNB 1937), paratopotype, collected by Philippe J. R. Kok, 27 April 1999.

Etymology - The species name is a noun in the genitive case honoring our esteemed colleague Taran Grant for his contribution to the taxonomic knowledge of the genus Colostethus, and the Dendrobatidae in general. 
Diagnosis - A very small species of Colostethus (males 14.9-16.7 mm SVL, females 14.718.4 mm SVL); body slender; Finger I longer than II when fingers appressed; Finger IV length not reaching distal subarticular tubercle on Finger III when fingers appressed; no distal tubercle on Finger IV; Finger III not swollen in adult males; basal webbing only between Toes II-IV; lateral fringes on fingers and toes absent; throat in adult males pale with discrete dark spotting to extensive stippling extending to chest (however, the throat is never totally gray or solid black), throat in females pale, free of melanophores; belly in males whitish, free of melanophores, belly in females yellowish, free of melanophores; dorsolateral stripe absent; oblique lateral stripe often barely distinct, when noticeable it is incomplete, very diffuse, consisting of a lighter or slightly lighter area [as suggested by Grant and Rodríguez (2001), we consider the diffuse, pale region located in the same area of the oblique lateral stripe as homologous with it]; ventrolateral stripe usually absent; median lingual process absent; cloacal tubercles absent; black arm-band absent in males; testis white (unpigmented) in adult males.

Description of holotype - An adult male; body slender; head wider than long, head length $88.2 \%$ width; head length $30.2 \%$ SVL; snout broadly round in dorsal view, acutely rounded in lateral view, extending past lower jaw, snout 48.9\% head length. Nares located laterally, opening posterolaterally; canthus rostralis rounded, loreal region flat, flaring slightly at upper lip; internarial distance $39.2 \%$ head width; eye-naris distance $28.9 \%$ head length, $59.1 \%$ diameter of eye. Tympanum nearly round, directed posterolaterally, $36.4 \%$ of eye length; separated from eye by a distance equal to $25 \%$ of tympanum diameter; supratympanic fold absent; tympanic annulus visible; posterodorsal aspect of tympanum barely visible; anteroventral margin of tympanum distinct. Tongue attached anteriorly, broadly rounded posteriorly, median lingual process absent. Choanae circular, lateral.
Vocal slits long, lateral. Small teeth present on maxillary and premaxillary, prevomerine teeth absent. Cloacal tubercles absent; vent at level of upper thighs; a small anal flap above vent. Dorsum smooth or weakly granular, with small scattered tubercles in sacral region; belly smooth (Figure 1).

Forelimb slender, skin smooth; ulnar fold absent; hand length 30.2\% SVL; Finger I longer than Finger II when fingers appressed; fingers unwebbed, lateral fringes absent; Finger III not swollen; Finger IV length not reaching distal subarticular tubercle on Finger III when fingers appressed; terminal discs expanded, wider than long, about 1.5 times the width of digit; width of disc on Finger III $0.40 \mathrm{~mm}$; discs with distinct dorsal scutes. Finger III > I > II > IV; palmar tubercle large, ovoid, $0.62 \mathrm{~mm}$ in diameter, $13.8 \%$ of hand length, surrounded by dark gray pigment; thenar tubercle small, elliptic, half the size and well separated from the palmar tubercle. One subarticular tubercle present on Fingers I, II, and IV; two subarticular tubercles on Finger III; basal subarticular tubercles on Fingers I, II, and III largest, subequal; basal subarticular tubercle on Finger IV and distal tubercle on Finger III smaller, subequal (Figure 2).

Hindlimb robust, skin granular; tibia length 47\% SVL; heels slightly overlapping when hindlimbs are flexed at right angles to sagittal plane of body; foot length $40.9 \%$ SVL; relative length of appressed toes IV > III > V > II > I; Toe I very short, reaching the base of subarticular tubercle on Toe II when toes appressed; discs on Toes II, III, IV, and V larger than width of toes; disc on Toe I with the same size as width of digit. Width of disc on Toe IV 0.60 $\mathrm{mm}$; rudimentary webbing present only between Toes II-IV; webbing unpigmented; lateral fringes absent. Toe webbing formula II $2^{+}-3 \frac{3}{4}$ III 3-33/4 IV. Inner metatarsal tubercle oval, $0.50 \mathrm{~mm}$ in length, outer metatarsal tubercle round, $0.33 \mathrm{~mm}$ in diameter, entirely pigmented; medial metatarsal tubercle absent on right foot, faint on left foot where it is slightly smaller than inner metatarsal tubercle. Two subarticular 
tubercles present on Toes III, IV and V, one on Toes I and II. Subarticular tubercles on Toes I and II largest, those on Toes III, IV and V slightly smaller. Weak outer metatarsal fold present. Tarsal keel on distal third of tarsus well defined, tuberclelike located $0.88 \mathrm{~mm}$ from proximal edge of inner metatarsal tubercle, distally faint and not reaching inner metatarsal tubercle (Figure 3).

Measurements of holotype ( $\mathrm{mm}$ ) - SVL 14.9, HL 4.5, HW 5.1, SL 2.2, EN 1.3, IN 2.0, EL 2.2, IO 1.9, TYM 0.8, FAL 3.5, HAND 3.6, WFD 0.4, TL 7.0, FL 6.1, WTD 0.6.

Color of holotype in life - Dorsal coloration medium brown with a few dark brown flecks on head and dorsum; a wide black band from tip of snout laterally around the body and above the vent; no dorsolateral stripe above this band. The oblique lateral stripe imbedded in the black band consists of a diffuse lighter area extending from the groin to about one-quarter of the distance to the arm insertion. Flanks are creamish white below the black band, no ventrolateral stripe discernible but a few small irregular white and gray blotches occur along flanks. Throat is creamish white with scattered tiny dark gray dots. Belly is immaculate creamish white. Upper lip is creamish white. Upper surfaces of thighs and shanks are dark gray with a black band and blotches. A pale paracloacal mark is present. Forelimbs are light reddish brown with a dark brown line on the posterior surface of forearms from elbow to wrist. A short black line extends from the anterior insertion of arm to about one-quarter of the distance to the elbow. Digits are dark gray with a few small white dots. Fingers are dark gray with a few small white dots. The upper surface of tympanum is black, the lower surface light gray. The iris is golden bronze (Figure 4).

Color of holotype in preservative - After seven years in preservative (70\% ethanol), the dorsum is light brown with some dark brown flecks; the lateral band is dark brown and the diffuse oblique lateral stripe is barely distinguishable. Flanks, belly, and upper lips are immaculate white. Throat is white; the tiny dark gray dots are visible under magnification only. Upper surface of thighs and shanks are brown with dark brown blotches and dark brown bands. The pale paracloacal mark is still visible. Forelimbs are light yellow; the short black lines are lighter but still visible. Fingers and digits are light brown. Tympanum is still discernible but lighter in coloration (brown).

Variation among type specimens - Descriptive statistics of the type series are in Table 1. A medial metatarsal tubercle occurs in four specimens (25\%) and is rarely well defined; when distinct, the medial metatarsal tubercle is rounded, smaller than or equal to the inner metatarsal tubercle. A basal third subarticular tubercle, very small or barely distinct, on toe IV of the right foot is present in six specimens; on the left foot, the same tubercle is present in five specimens. In life, dorsal coloration is grayish brown to dark reddish brown. The black band on thigh and shank is broken into blotches in some specimens. Flanks are creamish white in males, yellow in females; in some specimens, a few small irregular white (in males) or yellow (in females) and gray blotches occur along flanks and upper lips (Figure 4). In preservative, the dorsal coloration varies from gray to dark brown; other changes are similar to those observed in the holotype, with some variation depending on time spent in preservative. A distinct white ventrolateral stripe occurs in three preserved specimens from Montagne Kotika, but was not visible in life. Since the belly and flank coloration of the same specimens changed to pale pink in preservative (as did some internal organs), we speculate that the occurrence of this stripe is an artifact of preservation. Although we initially considered the possibility that these specimens were a distinct species, notably because of their slightly larger size and darker coloration and presence of a ventrolateral stripe 
Kok et al.

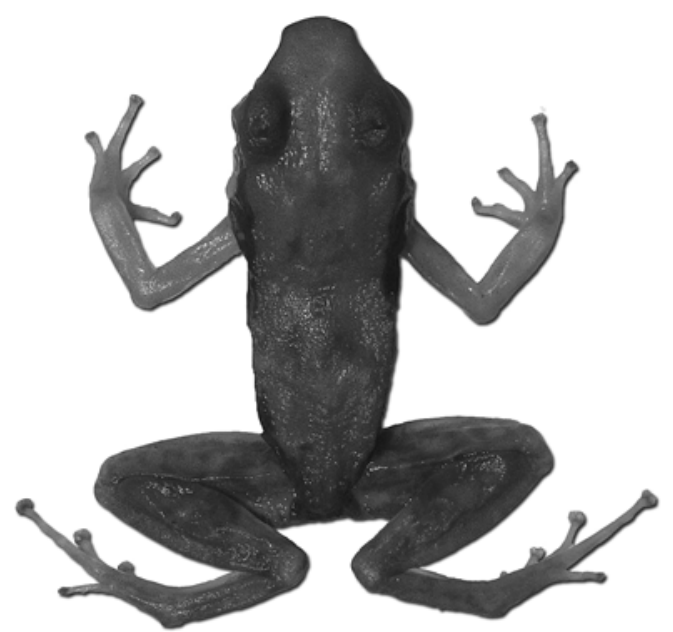

A

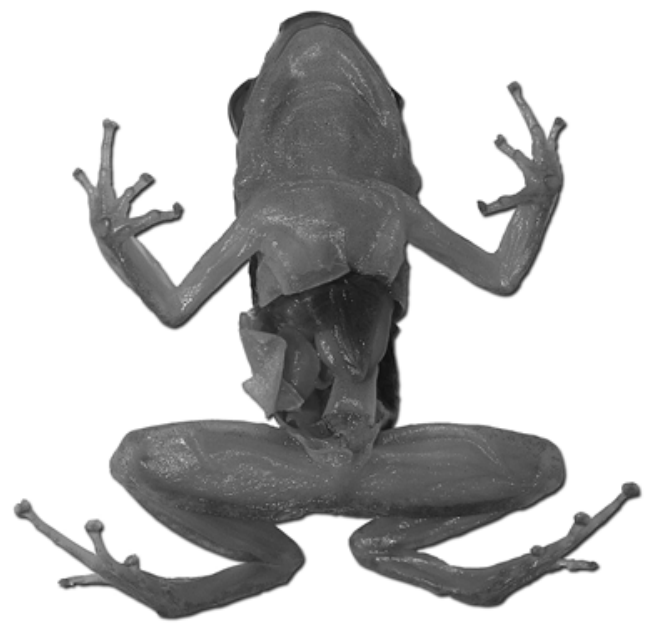

C

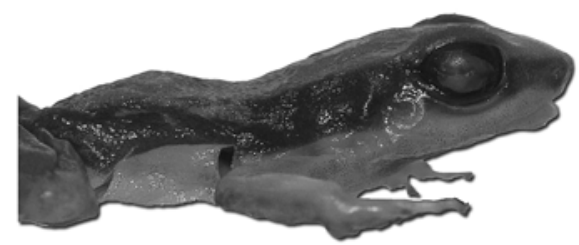

E

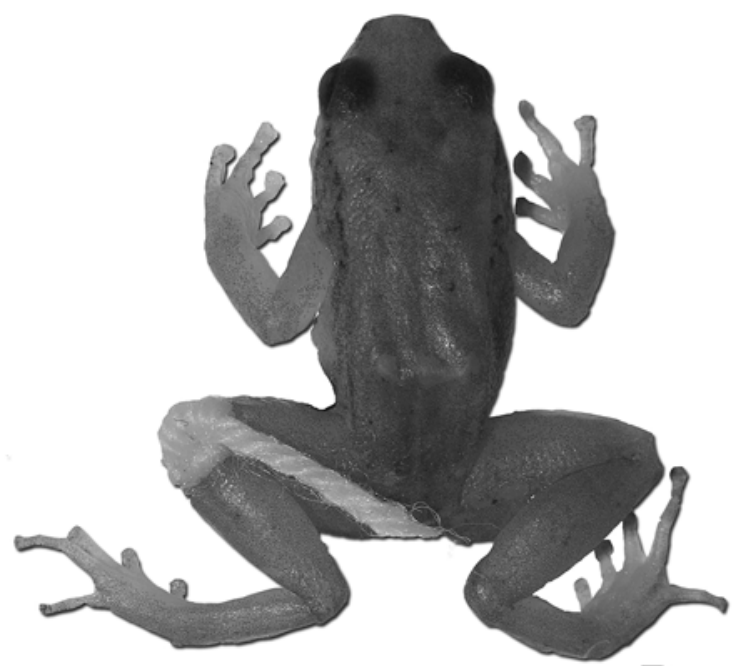

B
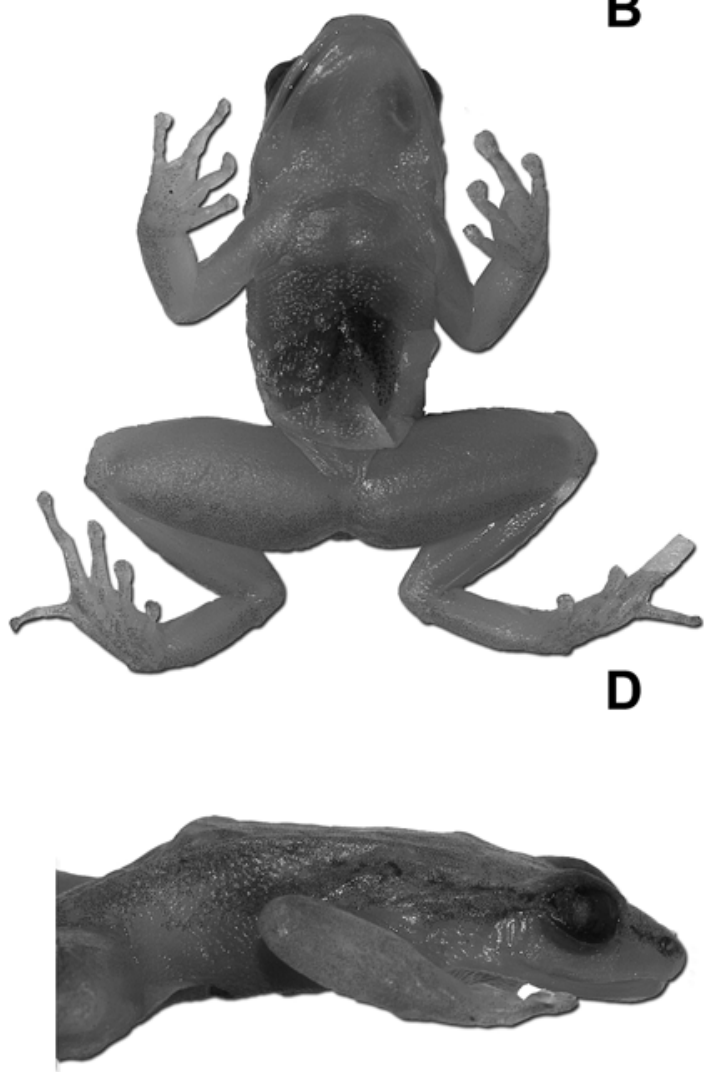

F

Figure 1 - (A, C, E) Dorsal, ventral, and lateral views of the holotype of Colostethus granti (IRSNB 1932); (B, D, F) Dorsal, ventral, and lateral views of Colostethus beebei from the type locality (IRSNB 13730). 

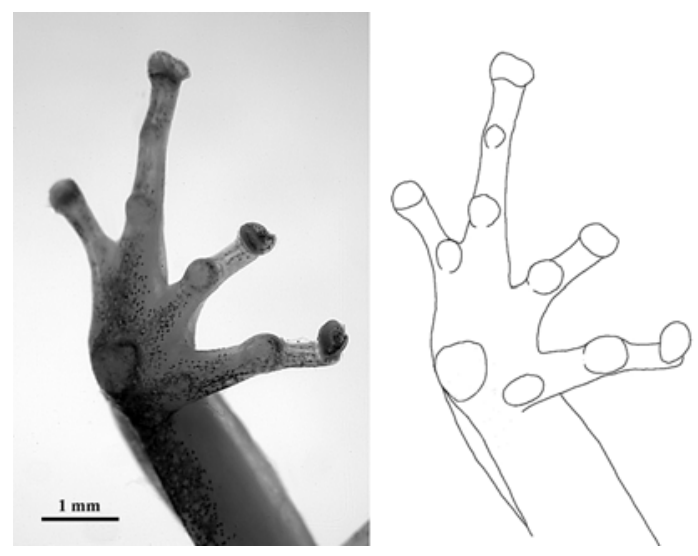

Figure 2 - Colostethus granti sp. nov. (holotype). Ventral view of hand. Photograph by J. Constant.
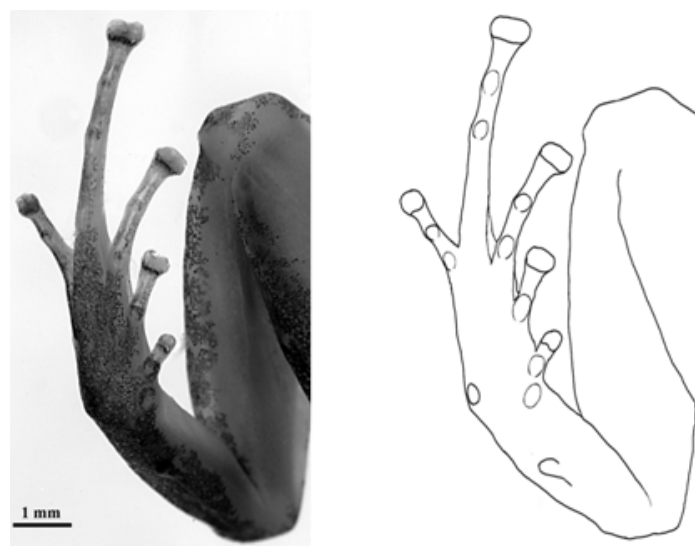

Figure 3 - Colostethus granti sp. nov. (holotype). Ventral view of foot. Photograph by J. Constant.

Comparison with other species - In lacking the median lingual process, in having the first finger longer than the second, and the third finger not distinctly swollen in males, Colostethus granti resembles only two species from the Guiana Shield and adjacent Venezuela: $C$.

Table 1 - Measurements of the type series of Colostethus granti sp. nov. Abbreviations are defined in the text. Mean $\pm \mathrm{SD}$ are followed by the range in parentheses.

\begin{tabular}{ccc}
\hline Character & Males $\mathbf{( N = 8 )}$ & Females $(\mathbf{N}=7)$ \\
\hline SVL & $16.15 \pm 0.55(14.9-16.7)$ & $16.80 \pm 1.18(14.7-18.4)$ \\
HL & $4.73 \pm 0.29(4.5-5.3)$ & $4.14 \pm 0.43(4.4-5.7)$ \\
HW & $5.28 \pm 0.18(5.0-5.5)$ & $5.29 \pm 0.28(4.8-5.6)$ \\
SL & $2.56 \pm 0.20(2.2-2.8)$ & $2.54 \pm 0.26(2.0-2.8)$ \\
EN & $1.48 \pm 0.15(1.3-1.7)$ & $1.49 \pm 0.11(1.3-1.6)$ \\
IN & $2.15 \pm 0.15(1.9-2.4)$ & $2.20 \pm 0.16(1.9-2.4)$ \\
EL & $2.36 \pm 0.12(2.2-2.5)$ & $2.43 \pm 0.22(2.2-2.8)$ \\
IO & $1.92 \pm 0.07(1.8-2.0)$ & $1.91 \pm 0.07(1.8-2.0)$ \\
TYM & $0.86 \pm 0.07(0.8-1.0)$ & $0.90 \pm 0.06(0.8-1.0)$ \\
FAL & $3.64 \pm 0.15(3.4-3.8)$ & $3.73 \pm 0.21(3.5-4.0)$ \\
HAND & $3.52 \pm 0.16(3.3-3.7)$ & $3.61 \pm 0.11(3.4-3.7)$ \\
WFD & $0.41 \pm 0.04(0.4-0.5)$ & $0.40 \pm 0.06(0.3-0.5)$ \\
TL & $7.48 \pm 0.27(7.0-7.8)$ & $7.63 \pm 0.31(7.2-8.0)$ \\
FL & $6.35 \pm 0.32(5.9-6.9)$ & $6.39 \pm 0.37(6.1-7.0)$ \\
WTD & $0.53 \pm 0.12(0.4-0.7)$ & $0.53 \pm 0.14(0.4-0.8)$ \\
\hline
\end{tabular}



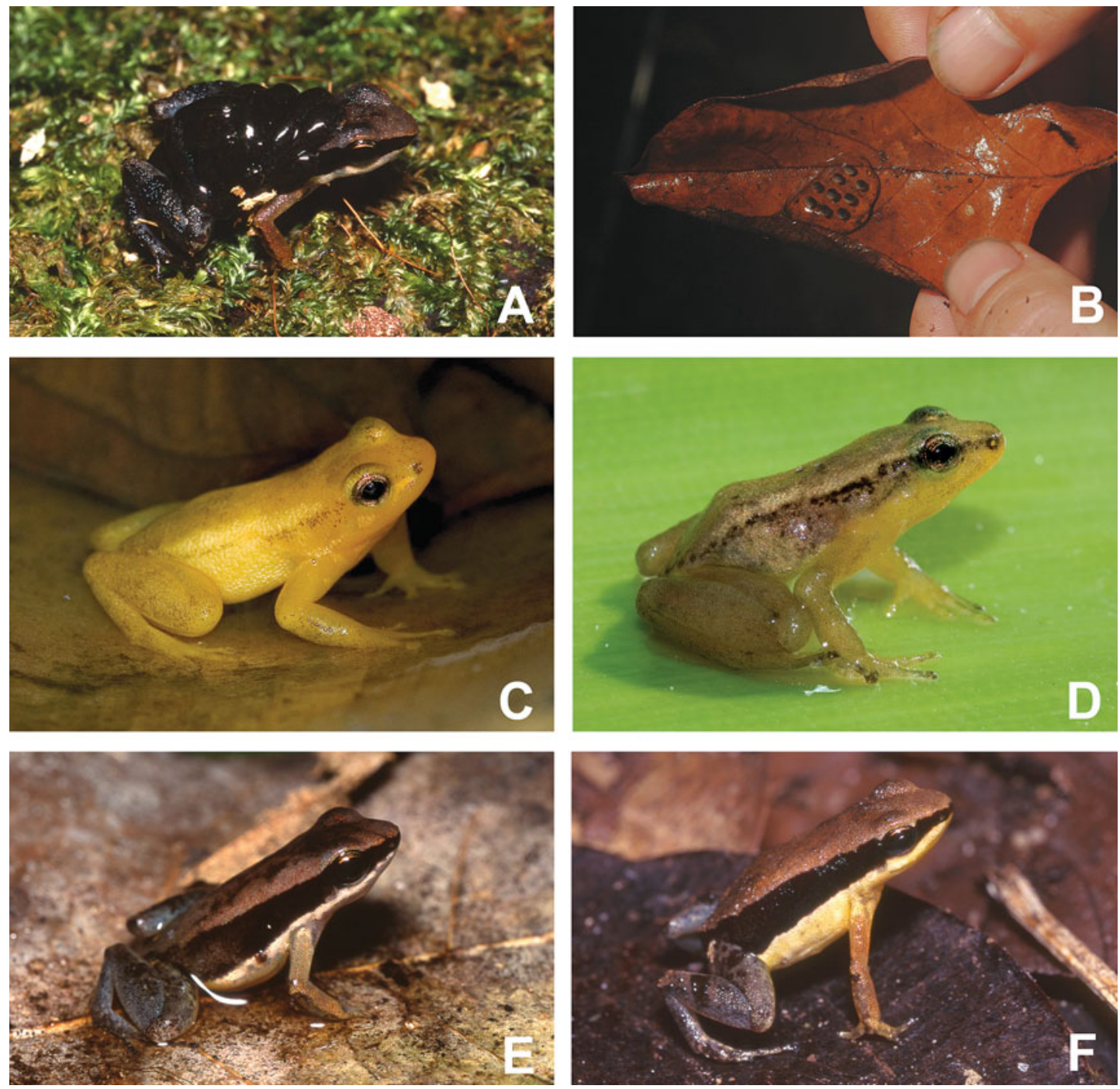

Figure 4 - (A) Colostethus granti sp. nov., holotype in life carrying 18 tadpoles in stage 25. Photograph by P. J. R. Kok; (B) Egg clutch of Colostethus granti sp. nov., with nine fertile eggs found inside a curled dead leaf on the forest floor. Photograph by O. Tostain; (C-D) Colostethus beebei from the type locality, showing bright yellow (C: uncollected specimen) and brown (D: IRSNB 13722, $15.8 \mathrm{~mm}$ SVL) color morphotypes. Photographs by P. J. R. Kok; (E-F): Colostethus granti sp. nov. Two paratopotypes showing variation of coloration and sexual dimorphism (E: IRSNB 1936, male, 16.3 mm SVL; F: ULABG 6816 (ex IRSNB 1937), female, $17.7 \mathrm{~mm}$ SVL). Photographs by P. J. R. Kok.

pittieri La Marca, Manzanilla, and MijaresUrrutia, 2004, and C. undulatus Myers and Donnelly, 2001. Colostethus pittieri differs in usually having a diffuse dorsolateral stripe (always absent in C. granti), but mostly in having a gray belly and black throat in males (belly white and throat never black in C. granti); C. undulatus is a larger species $(20.0-25.0 \mathrm{~mm}$ 
SVL vs. 14.7-18.4 mm SVL in C. granti), with a swollen supracarpal pad atop wrist in males (absent in C. granti) and with wavy-edged dorsal markings (absent in C. granti). Six extralimital Amazonian species lacking the median lingual process, having the first finger longer than the second, and having the third finger not distinctly swollen in males could also be confused with C. granti: C. brunneus (Cope, 1887), C. caeruleodactylus Lima and Caldwell, 2001, C. crombiei Morales, “2000” [2002], C. marchesianus (Melin, 1941), C. masniger Morales, “2000” [2002], and C. nidicola Caldwell and Lima, 2003. Colostethus brunneus (fide Cope 1887, southern populations only) is most easily distinguished from $C$. granti in usually having diamond shaped marks on dorsum ("hour glass" pattern; always absent in C. granti), tubercles on dorsum (smooth or weakly granular in C. granti), Fingers I and II equal in length (Finger I much longer than II in C. granti), and in having an incomplete lateral black band (always complete in C. granti); in life, C. caeruleodactylus is easily distinguished from C. granti in having blue digits on the hand and blue discs on the toes in males, and blue discs on the fingers and toes of females (never blue in C. granti); C. crombiei can be distinguished from $C$. granti by its larger size in males (17.4-19.0 mm vs. $14.9-16.7 \mathrm{~mm}$ in C. granti), by the presence of lateral fringes on toes (absent in $C$. granti), and by the dorsal pattern of diamond shaped marks (absent in C. granti); $C$. marchesianus differs from $C$. granti in having gray throat and chest in males (throat pale stippled with gray in $C$. granti) and in having wide distinct dorsolateral stripes (absent in $C$. granti); C. masniger differs in having a larger size in males (17.9-19.5 mm vs. $14.9-16.7 \mathrm{~mm}$ in C. granti), dorsolateral stripes (absent in $C$. granti), fringes on toes (absent in C. granti), and a dark gray belly in males (creamish white in $C$. granti); C. nidicola differs in having a solid black throat in males (throat pale stippled with gray in C. granti).

It should be noted that another undescribed species was collected in sympatry with $C$. granti around the village of Saül, central French Guiana. At the moment, only one specimen of this undescribed species is available to us and we prefer to await additional material to describe it. This undescribed species, possibly corresponding to "Colostethus sp. aff. marchesianus (B)” cited by Vences et al. (2003) (these specimens were not available to us), has different call characteristics and can be distinguished from C. granti, in part, by its smaller tympanum size and the aspect of the oblique lateral stripe. Undescribed Colostethus species from Brazil currently under study by Caldwell and colleagues apparently also have different calls (Caldwell in litt. to E. H. Poelman, 9 March 2005, Lima in litt. to E. H. Poelman, 14 March 2005). Males of the Venezuelan specimens of Colostethus "marchesianus" have an unpigmented throat and swollen Finger III (Morales 1994); as suggested by Caldwell et al. (2002), we did not consider this Venezuelan population as conspecific with specimens of $C$. marchesianus from the type locality, and, therefore, did not include these specimens in the present study.

Male secondary sexual characters - Males are slightly smaller than females (mean SVL in males $16.15 \mathrm{~mm}$; mean SVL in females 16.80 $\mathrm{mm}$ ), with a creamish white belly (yellow in females) and a pale throat stippled with melanophores (throat without melanophores in females). In males, throat spotting varies from a few scattered tiny gray dots (sometimes visible under magnification only) to extensive stippling extending to chest, but the throat is never deep gray nor solid black (Figures 4 and 5).

Tadpole description - A type 4 tadpole (Orton 1953), exotrophic, benthic type (Lannoo et al. 1987, Altig and Johnson 1989). Size small, up to $24.1 \mathrm{~mm}$ TL. Tail length 55-69\% TL, caudal musculature terminating anterior to tail tip, LTRF 2(2)/3(1), color dark brown with blue mottling in early stages, dark brown with dark mottling in later stages, venter transparent. 


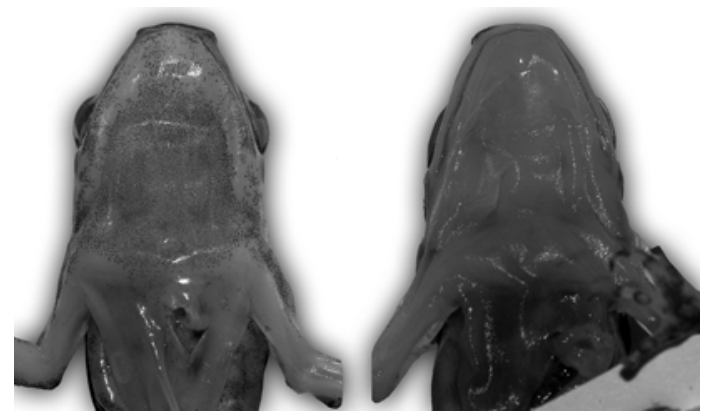

Figure 5 - Colostethus granti sp. nov. Ventral view of throat, male on left (MNHN 2005.0271), female on right (MNHN 2005.0270). Photographs by P. J. R. Kok.

We collected 18 back-riding individuals in stage 25 and four in stage 27 . One stage-27 larva was reared to stage 40 before preservation. The following is a description of MNHN 2005.0277, a specimen in stage 40. Snout truncate in dorsal view, rounded in lateral view; nares directed anterolaterally; eyes dorsal, directed laterally. Spiracle sinistral, a short tube, directed dorsolaterally, its base located $53 \%$ of body length from snout and $40 \%$ of body height from venter. Vent tube not visible. Tail musculature highest at body/tail junction, tapering posteriorly, terminating anterior to tail tip. Tail tip tapered. Upper fin originates posterior to junction of body and tail (Figure 6). Mouth ventral, oral disc not emarginate but laterally folded, width $1.4 \mathrm{~mm}$. Labial teeth long, in a single row, each with five cusps (Figure 7), LTRF 2(2)/3(1). Anterior rows slightly longer than posterior rows. Tooth row A-1 complete; A-2 consists of two short widely separated rows at level of upper jaw sheath. Tooth row P-1 slightly longer than P-2, medially interrupted. Tooth row P-2 with a small unnatural gap on left side. Tooth row P-3 shorter that $\mathrm{P}-1$ or $\mathrm{P}-2$, composed of short poorly keratinized teeth, with a small unnatural gap on the left side (Figure 6). Marginal papillae in a single row; a dorsal papillary gap approximately equal to the length of A-1. Papillae short, roundtipped. Submarginal papillae absent. Jaw sheaths serrated; lower jaw sheath broadly V-shaped; upper jaw sheath with long slender lateral processes (Figure 6).

Variation - Number of labial teeth and size of P-1 gap vary among individuals, even of the same stage. Tooth row P-3 is longer and much more distinct in smaller individuals, but always shorter than P-2 and P-1. Stage-25 tadpoles have fewer marginal papillae than later-stage individuals. Some stage-25 tadpoles have a small abdominal flap.

Measurements of tadpoles ( $\mathrm{mm}$ ) - Stage 40 ( $\mathrm{n}=1$ ): TL 24.1, BL 7.4, TAL 16.7, BW 4.9, BH 3.9, HW 3.3, TMH 1.6, TMW 1.7, MTH 3.6, greatest fin height 1.4, END 0.7, NSD 0.7 , IND 1.3, IOD 1.4, ED 1.3, limb length 9.3. Stage $25(\mathrm{n}=10)$ : TL 6.0-8.0, BL 2.72.9, TAL 3.3-5.1, BW 1.0-1.9, BH 0.7-1.3, HW 1.0-1.6, TMH 0.3-0.7, TMW 0.6-0.8, MTH 0.7-1.1. Stage $27(\mathrm{n}=3)$ : TL 10.3-11.6, BL 3.4-4.1, TAL 6.9-7.4, BW 2.9-3.0, BH 1.0-2.0, HW 1.7-2.0, TMH 0.6-0.9, TMW 0.91.0, МTH 1.4-1.9.

Color in life - In smaller individuals, dorsum of head and body is dark brown with black flecks, changing to black with scattered small blue flecks on sides, venter, tail musculature, and fin. A dark brown stripe extends from tip of snout to eye, a short dark brown stripe extends posterior from eye. Iris golden. Larger tadpoles are dark brown with scattered black flecks on tail musculature and fin. In preservative, the background color remains dark brown for some months, then fades to brown (pale yellowishbrown after a few years) with scattered melanophores clumped into irregular blotches on tail musculature and fin.

Comparison with other Colostethus tadpoles - The exotrophic tadpole of C. granti is immediately distinguishable from those endotrophic tadpoles of C. degranvillei, C. nidicola, and C. stepheni Martins, 1989, which lack keratinized 

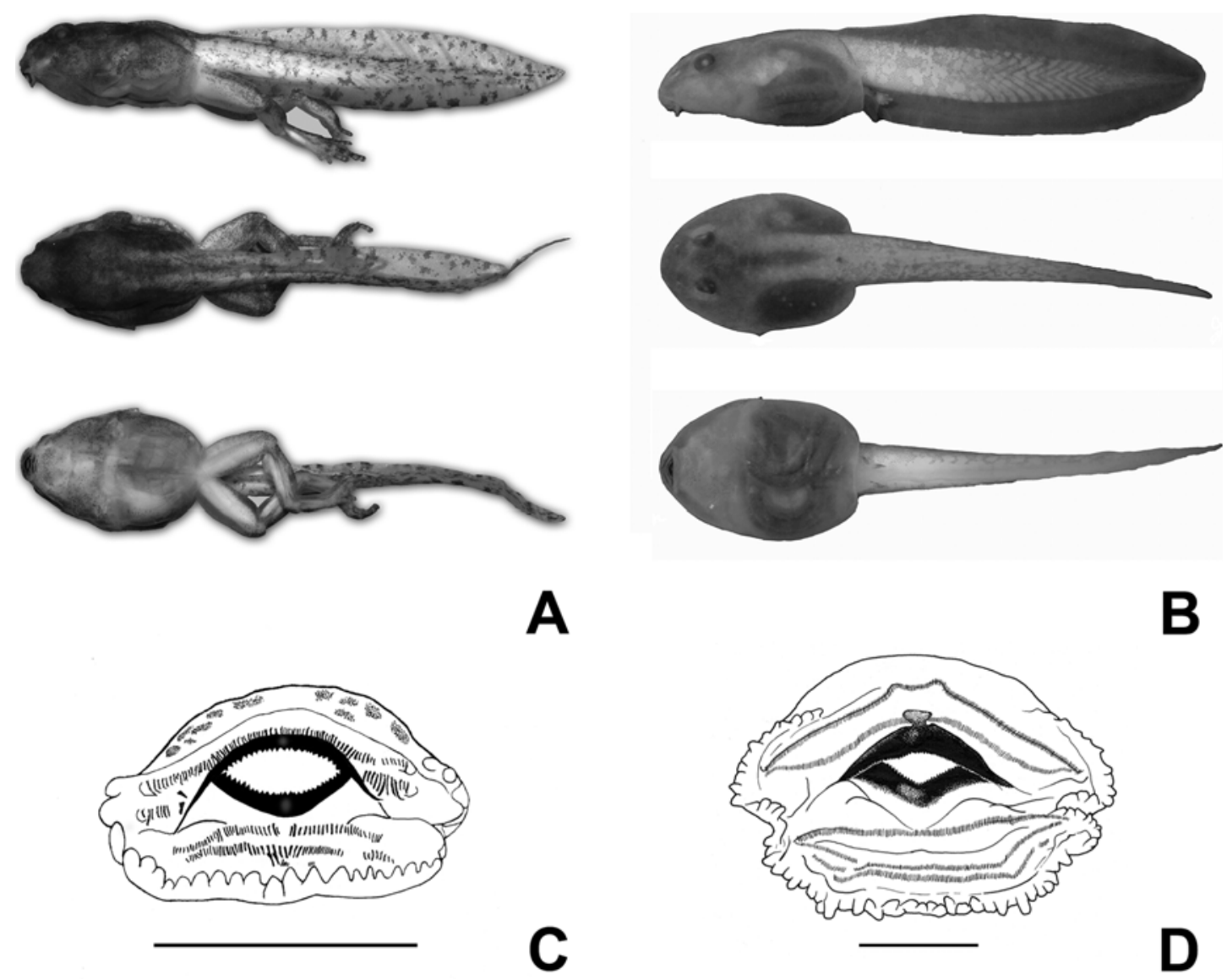

B

Figure 6 - (A) Tadpole of Colostethus granti sp. nov., MNHN 2005.0277 from Montagne Kotika, Stage 40, 24.1 mm TL. Photograph by P. J. R. Kok. (B) Tadpole of Colostethus beebei from the type locality, ROM 42994, stage 37, $29 \mathrm{~mm}$ TL. Photograph by A. Lathrop. (C) Oral disc of tadpole of Colostethus granti sp. nov., MNHN 2005.0277, stage 40. Width of disc is $1.4 \mathrm{~mm}$. Scale bar is $1 \mathrm{~mm}$. (D) Oral disc of tadpole of Colostethus beebei, ROM 42994, stage 37. Width of disc is $2.5 \mathrm{~mm}$. Scale bar is $1 \mathrm{~mm}$.

and typical oral structures (cf. Lescure 1984, Juncá et al. 1994, Caldwell and Lima 2003). When compared to tadpoles of other species of Colostethus from the Guiana Shield and extralimital Amazon Basin, C. granti differs from $C$. beebei by smaller size (up to $24.1 \mathrm{~mm}$ in $C$. granti, up to $32 \mathrm{~mm}$ in $C$. beebei), LTRF formula $(2(2) / 3(1)$ in $C$. granti; 2(2)/3 in $C$. beebei), C. beebei further differs by phytotelmata-dwelling habitat (benthic in C. granti); from C. marchesianus and C. caeruleodactylus by the size of marginal papillae (greatly enlar- ged in C. marchesianus and C. caeruleodactylus; short in C. granti); from C. parkerae Meinhardt and Parmelee, 1996 by LTRF formula $(2(2) / 3(1)$ in $C$. granti; 2(2)/3 in $C$. parkerae); from $C$. pittieri by LTRF formula (2(2)/3(1) in C. granti; 2/3 in C. pittieri); from C. tamacuarensis Myers and Donnelly, 1997 and $C$. undulatus by LTRF formula (2(2)/3(1) in C. granti; 2(2)/3 in C. tamacuarensis and $C$. undulatus), and by the oral disc not emarginate (emarginate in C. tamacuarensis and C. undulatus); from C. wothuja Barrio-Amorós, Fuentes 


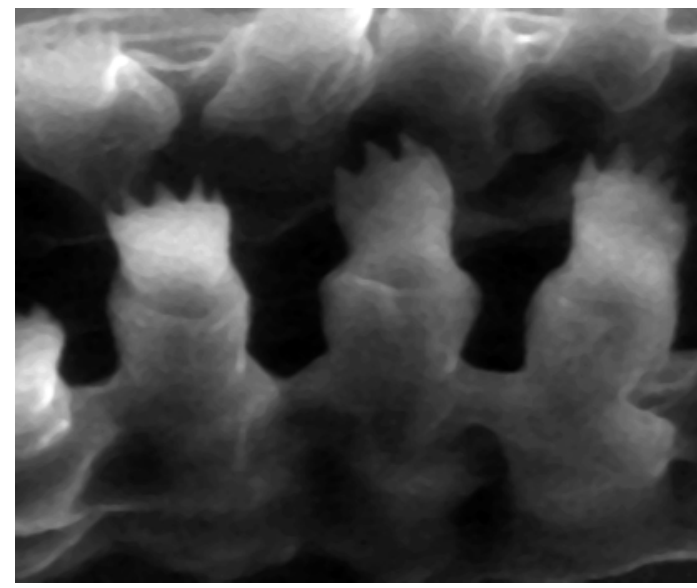

Figure 7 - Photomicrograph of labial teeth of Colostethus granti sp. nov.

and Rivas, 2004 in having an oral disc not emarginate (emarginate in C. wothuja). Tadpoles of other Colostethus from the Guiana Shield have not been described.

Vocalization - Quantitative measures of spectral parameters of the cricket chirp like trills of three males of Colostethus granti exhibited low variation among individuals (mean $\pm 1 \mathrm{SD}$; range) for lower $(5.10 \pm 0.18 \mathrm{kHz} ; 4.96-5.31)$ and upper (6.62 $\pm 0.26 \mathrm{kHz}$; 6.36-6.87) frequencies. Temporal parameters of the call were highly variable among individuals for calls/min (29.28 \pm 5.94; 22.45-33.29), notes/call (6.23 \pm 2.59 ; $1-17$ or on average of individuals 3.91 9.03), and call duration (1.33 $\pm 0.56 \mathrm{sec}$; 0.14 4.48 or on average of individuals $0.84-1.94$ ); intercall interval $(0.76 \pm 0.12 \mathrm{sec}$; $0.46-1.78$ or on average of individuals $0.67-0.89$ ) and internote interval (156.44 $\pm 10.42 \mathrm{~ms} ; 110-250$ or on individuals 145.76-166.57; Figure 8) denoted low variation among individuals.

Natural History - Colostethus granti is a strictly diurnal, forest-dwelling species not closely associated with bodies of water. Males are territorial, call from the leaf litter, and do not climb into vegetation. In the Nouragues Nature Reserve $\left(04^{\circ} 05^{\prime} \mathrm{N}, 52^{\circ} 41^{\prime} \mathrm{W}\right.$, elevation $\mathrm{ca} .100$

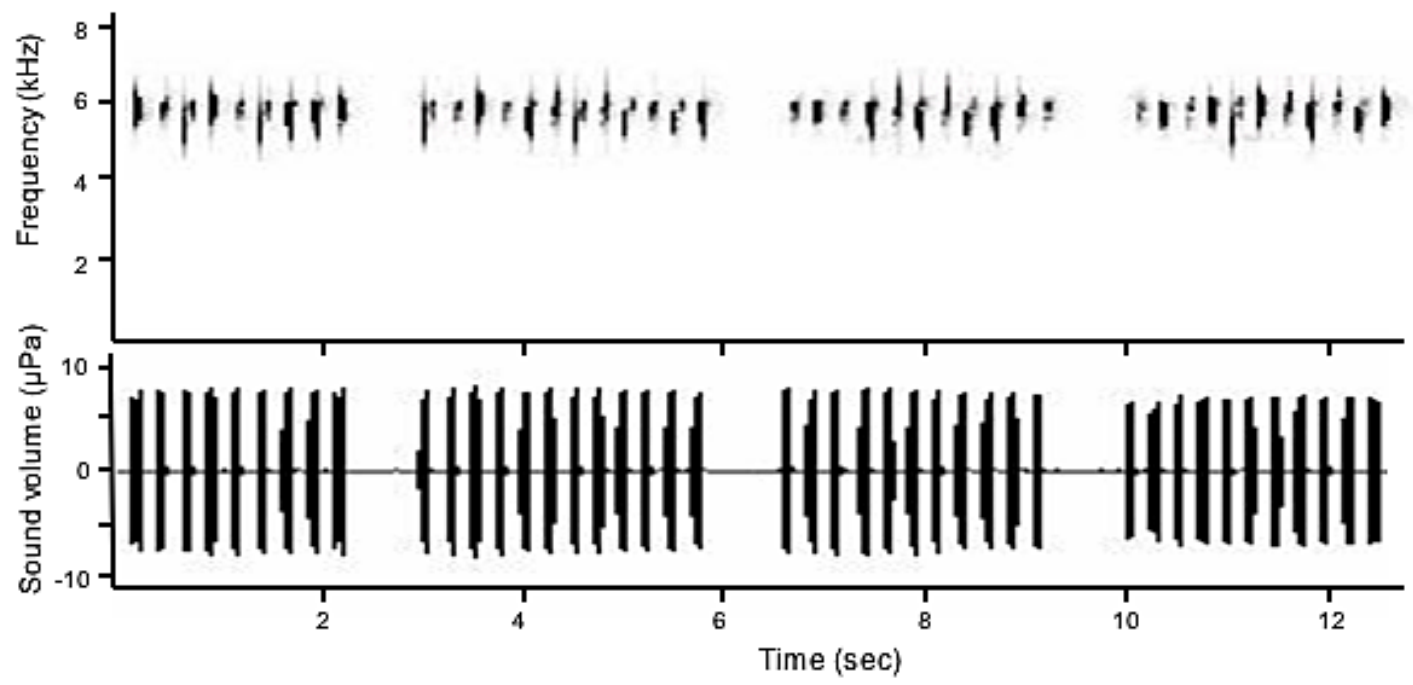

Figure 8 - Audiospectrogram (top) and amplitude waveform (bottom) of advertisement calls of Colostethus granti (MNHN 2005.0268) from Haute Wanapi, French Guiana. Colostethus granti advertisement calls are repetitions of one up to seventeen chirps about $1.33 \pm 0.32 \mathrm{sec}$ in duration. The waveform illustrates relative amplitude (sound volume) that is reflected in the height of the spikes above and below the $0 \mathrm{mPa}$ axis. 
$\mathrm{m})$, a population was found on a small rise in the forest floor in a sunlit clearing in primary forest. Understory vegetation covered $c a$. $30 \%$ of the forest floor clearing, and bromeliads (both terrestrial and epiphytic) were absent. Approximately 30 males were observed within $100 \mathrm{~m}$ of a small stream. Males selected calling sites on large leaves on the forest floor and were barely visible due to their cryptic coloration. Calling males exhibited site fidelity, returning to their calling site following disturbance. Calling males were positioned 2-6 m (mean $4 \mathrm{~m}$ ) apart. Similar observations were made at the type locality and in the vicinity of Pic Matécho (034' N, 53⒉ W, elevation ca. $280 \mathrm{~m}$ ). Colostethus granti seems more heliophilic than other sympatric species such as $C$. degranvillei (found along small streams) and C. baeobatrachus (found in closed-canopy forest).

Reproduction does not appear to be seasonally constrained. Courtship and late-stage tadpoles have been observed in February and March. Females collected in February, April, May, July, and November contain mature pigmented oocytes of 0.7-1.4 mm diameter. Colostethus granti has a typical primitive reproductive mode, eggs are laid in the leaf litter and both sexes have been observed carrying tadpoles. It appears that the entire clutch of tadpoles is carried simultaneously. One female collected in February carried eight tadpoles in stage 27, one male collected in June carried 18 tadpoles in stage 25 (Figure 4). Deposition of tadpoles was not observed, although in both cases the only water in the vicinity was a small stream.

A courtship sequence was observed on Montagne Kotika on 19 February 2005 at 14:00 h. A calling male changed its call when a female approached within $c a .30 \mathrm{~cm}$. The call changed from a trill to a single "chirp", upon which the female approached further. Followed by the female, the male then moved $c a .2 \mathrm{~m}$ from its calling site to the interior of a curled dead leaf. Both stayed inside the dead leaf at least until nightfall. The next morning, the male was observed, silent, close to its previous calling

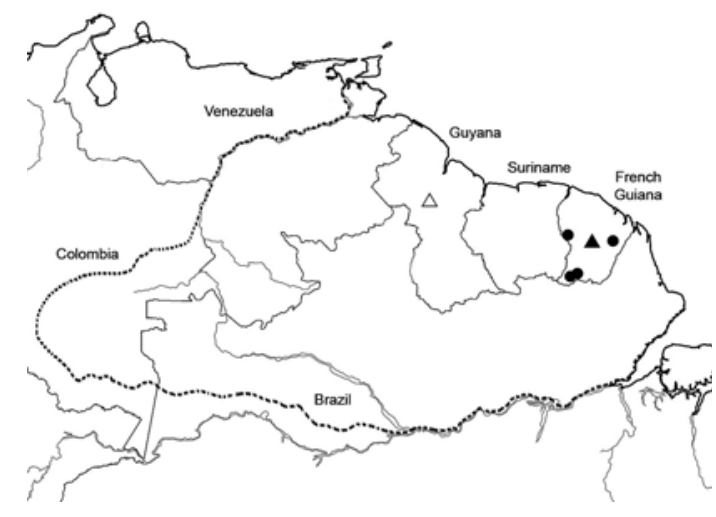

Figure 9 - Map of northeastern South America (limits of the Guiana Shield are in dotted lines) showing the distribution of Colostethus beebei (open symbols; triangle = type locality) and the localities of type specimens of Colostethus granti sp. nov. (closed symbols; triangle = type locality).

site. The dead leaf was opened and contained 9 fertile eggs (Figure 4).

Distribution - The species is currently known only from French Guiana, at elevations between 100 and $730 \mathrm{~m}$ (Figure 9). Colostethus granti may be present in Suriname (M. S. Hoogmoed, pers. comm.) and adjacent Brazil.

\section{Redescription of Colostethus beebei (Noble, 1923)}

Figures 1 (B, D, F), 4 (C, D), 7 (B, D), 10

Hyloxalus beebei Noble, 1923 [Holotype AMNH A-18683, from "near Kaieteur Falls, British Guiana”].

Phyllobates brunneus Barbour and Noble, 1920: Cochran (“1954” [1955]), Cochran and Goin (1970).

Colostethus beebei Edwards, 1971.

Diagnosis - A small species of Colostethus (males 11.5-16.8 mm SVL, females 16-18.7 mm SVL); body robust; Finger I shorter than II when fingers appressed; Finger IV length reaching 
distal tubercle on III when fingers appressed; distal tubercle on Finger IV; Finger III not swollen in adult males; toes webbed; throat and chest yellow in both sexes; belly free of melanophores in both sexes; dorsolateral stripe present; oblique lateral stripe present or absent; ventrolateral stripe absent; median lingual process present; cloacal tubercles absent; black armband absent in males; testes white (unpigmented) in adult males; tadpole heterotrophic.

Adult description - Descriptive statistics are in Table 2. Body stout, head wider than long, its width 1.2-1.3 times the head length; head length 26-30\% SVL; snout length 40-45\% head length, broadly round in dorsal view, rounded in lateral view, extending past lower jaw; lower jaw extends to a level equal to the posterior edge of the nares. Nares located laterally, opening anterolaterally; canthus rostralis rounded, loreal region slightly concave; internarial distance $35 \%$ head width; eye-naris distance $60-65 \%$ eye length; interorbital distance 1.5 times the upper eyelid width; lower lip with a small medial projection that fits into an indentation in upper lip. Tympanum indistinct, circular, its horizontal diameter $50 \%$ of the eye length, posterodorsal aspect partially obscured, separated from eye by a distance of $50-60 \%$ of the tympanum diameter. Tongue attached anteriorly, rounded posteriorly, median lingual process present. Choanae circular, lateral. Vocal slits long, lateral. Teeth present on maxillary and premaxillary, prevomerine teeth absent. Skin on dorsum, flanks, dorsal surfaces of limbs, chin, throat, and venter granular; underside of limbs and rear of thigh shagreened or smooth. Vent at level of upper thighs; a distinct anal flap above vent; no enlarged tubercles near cloacal opening (Figure 1).

Forelimb slender, ulnar fold absent; hand length 28-31\% SVL; Finger I shorter than II, tip of I reaching midpoint of penultimate phalange of II when appressed; relative lengths of appressed fingers III > IV > II > I; Finger III not swollen in males; palmar tubercle heart-shaped, thenar tubercle oval; one subarticular tubercle on Fingers I and II, two on Fingers III and IV; fingers unwebbed, fringes present on II and III;

Table 2 - Measurements of adults and juveniles of Colostethus beebei from Kaieteur National Park. Abbreviations are defined in the text. Mean \pm SD are followed by the range in parentheses.

\begin{tabular}{cccc}
\hline Character & Males $(\mathbf{N}=\mathbf{1 8})$ & Females $(\mathbf{N}=27)$ & Juveniles (N=8) \\
\hline SVL & $15.5 \pm 1.02(13.2-16.8)$ & $17.8 \pm 0.65(16-18.7)$ & $12.9 \pm 1.3(11.2-14.3)$ \\
HL & $4.4 \pm 0.2(4.0-4.6)$ & $4.9 \pm 0.26(4.3-5.4)$ & $3.8 \pm 0.09(3.3-4.0)$ \\
HW & $5.6 \pm 0.38(4.8-6.1)$ & $6.1 \pm 0.15(5.7-6.3)$ & $4.7 \pm 0.11(4.2-5.1)$ \\
SL & $2.1 \pm 0.03(1.8-2.3)$ & $2.3 \pm 0.08(2.2-2.5)$ & $1.7 \pm 0.12(1.5-1.8)$ \\
EN & $1.2 \pm 0.06(1.1-1.3)$ & $1.4 \pm 0.08(1.2-1.5)$ & $1.0 \pm 0.11(0.8-1.1)$ \\
IN & $2.0 \pm 0.13(1.8-2.2)$ & $2.2 \pm 0.08(2.0-2.3)$ & $1.6 \pm 0.27(1.3-1.9)$ \\
EL & $2.1 \pm 0.09(1.9-2.2)$ & $2.2 \pm 0.07(2.0-2.3)$ & $1.9 \pm 0.27(1.5-2.2)$ \\
IO & $2.0 \pm 0.15(1.7-2.2)$ & $2.1 \pm 0.12(1.9-2.3)$ & $1.6 \pm 0.25(1.3-1.9)$ \\
TYM & $0.8 \pm 0.02(0.6-0.8)$ & $0.8 \pm 0.09(0.6-1.0)$ & $0.6 \pm 0.02(0.5-0.7)$ \\
FAL & $3.9 \pm 0.33(3.1-4.3)$ & $4.2 \pm 0.22(3.7-4.5)$ & $3.1 \pm 0.41(2.6-3.6)$ \\
HAND & $4.5 \pm 0.4(3.7-5.0)$ & $4.9 \pm 0.17(4.6-5.1)$ & $3.8 \pm 0.5(3.1-4.3)$ \\
WFD & $0.6 \pm 0.01(0.5-0.7)$ & $0.6 \pm 0.06(0.5-0.7)$ & $0.5 \pm 0.13(0.3-0.6)$ \\
TL & $7.4 \pm 0.4(6.3-8.0)$ & $8.0 \pm 0.31(7.5-8.7)$ & $6.2 \pm 0.79(5.2-7.1)$ \\
FL & $6.1 \pm 0.4(5.3-6.5)$ & $6.6 \pm 0.19(6.2-7.0)$ & $5.3 \pm 0.74(4.1-6.1)$ \\
WTD & $0.5 \pm 0.1(0.4-0.6)$ & $0.6 \pm 0.06(0.4-0.7)$ & $0.4 \pm 0.09(0.3-0.5)$ \\
\hline
\end{tabular}


discs larger than adjacent phalange, with distinct dorsal scutes; disc on Finger III 0.6-0.7 $\mathrm{mm}$ in adults, 0.3-0.5 mm in juveniles (Figure 10).

Hindlimb robust, shank $45-50 \%$ SVL in adults, $40-47 \%$ SVL in juveniles; heels in contact or narrowly separated when hindlimbs are flexed at right angles to sagittal plane of body; foot length 35-40\% SVL; relative length of appressed toes IV $>$ III $>$ V > II $>$ I; Toe I reaching distal edge of subarticular tubercle on Toe II; discs larger than adjacent phalanges; disc on Toe IV 0.5-0.6 mm in adults, $0.3-0.4 \mathrm{~mm}$ in juveniles. Toe webbing formula I 1 -2 II $1 \frac{112-}{2}$ $\left(2 \frac{1}{2}-23 / 4\right)$ III $\left(2-2 \frac{1}{4}\right)-2 \frac{3}{4}$ IV $\left(3-3^{+}\right)-23 / 4$ V, with fringes on all toes except outer edges of I and V. Inner metatarsal tubercle oval, outer round; an oval medial metatarsal tubercle present, often indistinct. Outer metatarsal fold present. Tarsal keel poorly defined, sometimes indistinct (Figure 10).

Bourne et al. (2001) provided SVL measurements for a much larger number $(\mathrm{N}=392)$ of released individuals from Kaieteur National Park.

The specimens collected in 2004 and 2005 conform well to the description of the holotype (Noble 1923), with the following exceptions: fringe present on toes (absent in original description), dorsal skin granular (smooth). The original description was based on a single specimen, and skin characters are subject to changes due to conditions of preservation.

Color in life - Adult coloration is variable, with two background colors; bright yellow/ orange and pale brown (Figure 4). Cream dorsolateral stripes and dark brown markings are present or absent, producing five color patterns, described in detail by Bourne (2001). In juveniles, the background color is green by night and yellow-green by day, slightly darker than adult coloration. Palpebral membrane unpigmented, no dark line along its upper edge. Additional photographs of $C$. beebei, and of its habitat, are in Kok et al. (2005).

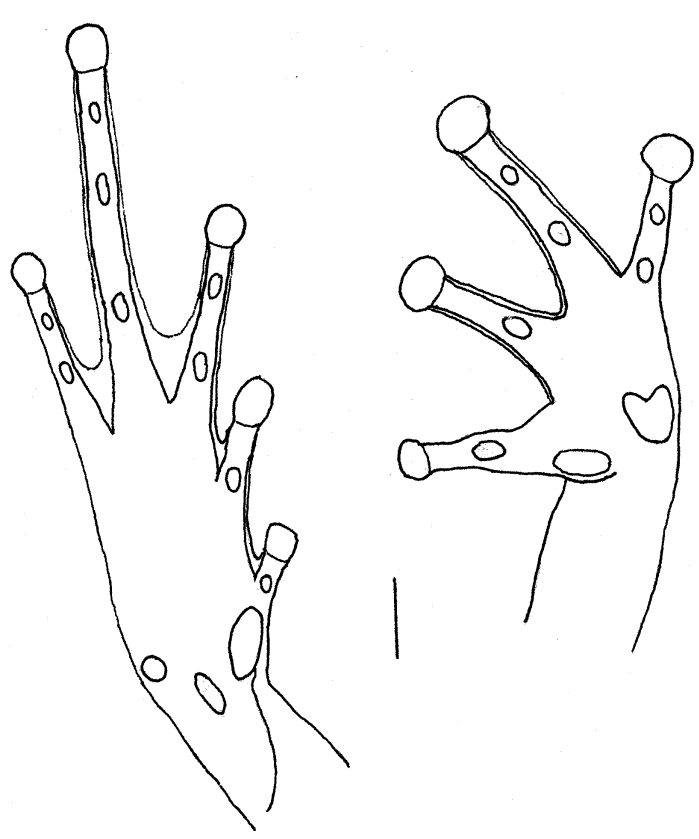

Figure 10 -Colostethus beebei, ventral view of hand and foot. Scale bar is $1 \mathrm{~mm}$.

Color in preservative - The background color fades to pale dull yellow. The bright cream dorsolateral lines become white. Dark markings are unchanged.

Comparison with other species - When compared to other species of Colostethus from the Guiana Shield region, Colostethus beebei is easily distinguished from C. brunneus (fide Cope 1887, southern population only), $C$. fuliginosus Jiménez de la Espada, 1871, $C$. granti, C. sanmartini Rivero, Langone, and Prigioni, 1986, C. sumtuosus Morales, “2000” [2002], and C. undulatus by the presence of a median lingual process (absent in C. brunneus, C. fuliginosus, C. granti, C. sanmartini, C. sumtuosus, and C. undulatus). Colostethus beebei differs from C. ayarzaguenai La Marca, “1996” [1997], C. guanayensis La Marca, “1996” [1997], C. degranvillei, C. parkerae Meinhardt and Parmelee, 1996, C. tamacua- 
rensis, and C. tepuyensis La Marca, “1996” [1997] by adult size (adult SVL $<19 \mathrm{~mm}$ in $C$. beebei; > $19 \mathrm{~mm}$ in C. ayarzaguenai, C. degranvillei, C. guanayensis, C. parkerae C. tamacuarensis, and $C$. tepuyensis); from $C$. baeobatrachus in having Finger I shorter than II (longer in C. baeobatrachus; $c f$. Kok 2000a) and in having Finger III not swollen in males (swollen in C. baeobatrachus; cf. Kok 2000a); from Colostethus murisipanensis La Marca, “1996” [1997] by the absence of dark spots on throat, chest, and venter (present in C. murisipanensis), smaller size in males (maximum SVL $17 \mathrm{~mm}$ in C. beebei; $19.1 \mathrm{~mm}$ in C. murisipanensis), and dorsum yellow or pale brown (grayish-brown in C. murisipanensis); from C. stepheni in having more extensive toe webbing and Finger III not swollen in males (swollen in C. stepheni); from C. parimae La Marca, “1996” [1997] by smaller female size (SVL 16.0-19.0 mm in C. beebei; 22.0-23.1 mm in C. parimae); from C. shrevei Rivero, 1961 by smaller male size (SVL 13.2$17.0 \mathrm{~mm}$ in $C$. beebei; $19.3-21.5 \mathrm{~mm}$ in $C$. shrevei); from C. praderoi La Marca, "1996” [1997] by the presence of dorsolateral stripes (absent in C. praderoi); from C. roraima $\mathrm{La}$ Marca, “1996" [1997] by the presence of webbing between all toes (webbing present only between toes III and IV in C. roraima); from $C$. triunfo Barrio-Amorós, Fuentes and Rivas, 2004 by granular dorsum (smooth in C. triunfo), and more extensive toe webbing, a maximum of three phalanges free (four phalanges free in $C$. triunfo); from $C$. wothuja by Finger I < II and dorsum yellow or light brown (Finger I > II, dorsum dark brown in C. wothuja).

Male secondary sexual characters - Apart from a slightly smaller size in males (mean SVL in males $15.3 \mathrm{~mm}$; mean SVL in females $17.8 \mathrm{~mm}$ ), we did not observe any other sexual dimorphism.

Tadpole description - A Type 4 tadpole (Orton 1953), exotrophic, arboreal Type 2 (Lannoo et al. 1987, Altig and Johnson 1989). Size typical for tadpoles of Colostethus, up to
$32 \mathrm{~mm}$ total length (TL). Tail length 58-65\% $\mathrm{TL}$, caudal musculature terminating anterior to tail tip, LTRF 2(2)/3, color yellow with dark mottling, venter transparent, found exclusively in phytotelmata.

Fifteen individuals in stage 25 and one in stage 37 were collected. The following is a description of ROM 42994, a specimen in stage 37. Snout round in dorsal and lateral profiles, nares directed anterolaterally, eyes dorsal, directed anterolaterally. Spiracle sinistral, a short tube, directed dorsolaterally, its base located $45 \%$ of body length from snout and 35\% of body height from venter. Vent tube distinct, dextral. Tail musculature highest at body/tail junction, tapering posteriorly, terminating anterior to tail tip. Tail tip rounded. Upper fin originates posterior to junction of body and tail. Dorsal fin equal in height to ventral fin (Figure 6). Mouth ventral, oral disc not emarginate but laterally folded, width $2.5 \mathrm{~mm}$. Labial teeth long, LTRF 2(2)/3. Anterior rows slightly longer than posterior rows, $\mathrm{P}-3$ shorter than $\mathrm{P}-1$ or $\mathrm{P}-2$. Papillae in a single row, a wide medial gap in upper labium. Papillae tapered, blunt-tipped. Jaw sheaths of moderate width, serrate; each side of upper sheath sigmoid, lower sheath Vshaped (Figure 6).

Variation - In general, larger tadpoles have a smaller A-2 gap and smaller anterior papillary gap than do smaller tadpoles.

Measurements of tadpoles ( $\mathrm{mm})$ - Stage 37 (ROM 42994): TL 28.7, BL 10.1, TAL 18.6, BW 6.7, BH 4.8, HW 5.5, TMH 3.1, TMW 2.5, MTH 6.5, greatest fin height 1.8, END 0.7, NSD 1.7, IND 1.8, IOD 1.6, ED 1.0, VTL 1.0, limb bud length 1.5. Stage $25(\mathrm{n}=15)$ : TL 16.0-32.0; BL 6.012.0; TAL 10.0-20.5 (58-64\% TL); BW 3.8-8.0; BH 2.7-5.0 (61-74\% BW); HW 3.4-6.2 (75-90\% BW); TMH 1.8-3.7; TMW 1.2-3.3; МТH 3.0-5.5.

Color in life - Body and tail typically pale yellow dorsally. A reddish wash present on the throat, possibly due to heart and blood vessels 


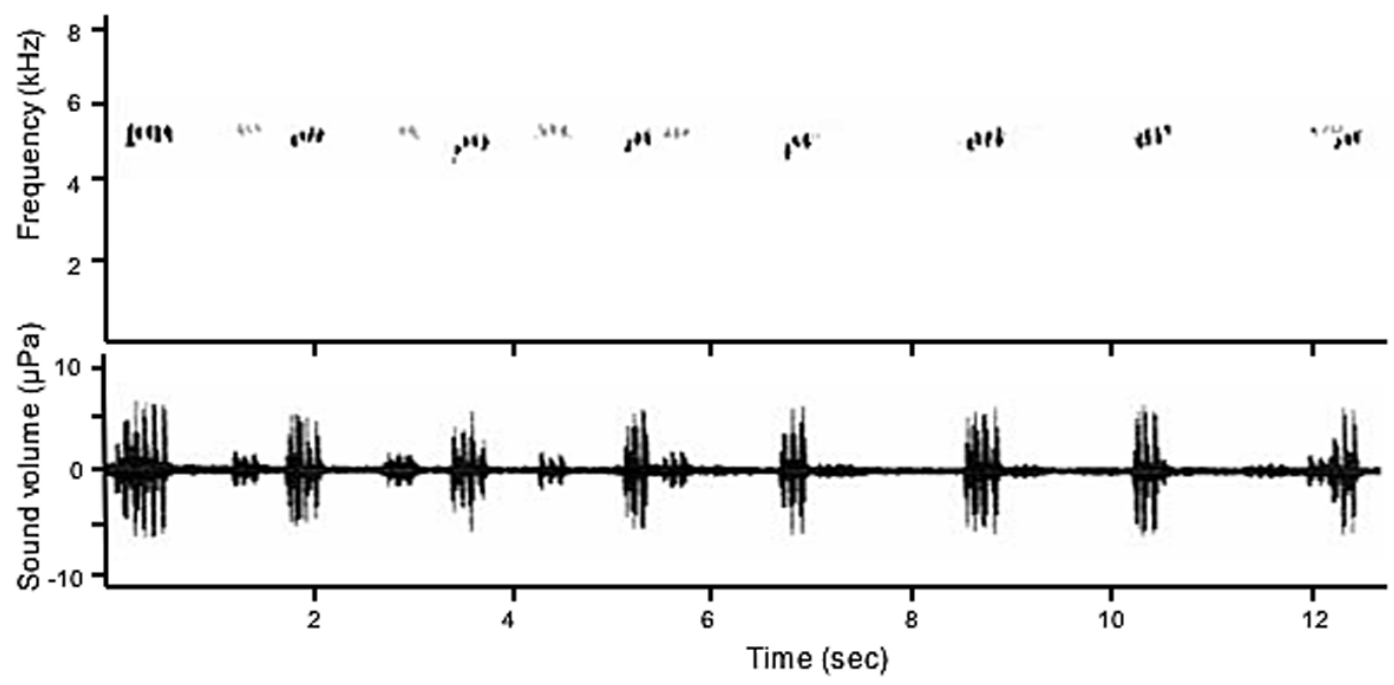

Figure 11 - Audiospectrogram (top) and amplitude waveform (bottom) of advertisement calls of two uncollected males of Colostethus beebei from Kaieteur National Park Guyana, calling antiphonally with male, FS20, closer to the microphone producing the darker tracings in the sonogram and the higher spikes in the waveform. Temperature during recording was $27^{\circ} \mathrm{C}$. Colostethus beebei advertisement calls are whistled trills made up of from 2 to 5 frequency-modulated notes or syllables about $58.95 \pm 1.87 \mathrm{~ms}$ in duration. The waveform illustrates relative amplitude (sound volume) that is reflected in the height of the spikes above and below the $0 \mathrm{mPa}$ axis.

visible through the skin. Venter appears dark because of gut visible ventrally and laterally through skin. Some individuals have dark gray coloration, ranging from a few scattered flecks on head, body and tail to extensive dark mottling on all surfaces. Dark mottling appears to be more common in smaller individuals; the largest darkly mottled individual is $26 \mathrm{~mm}$ TL. Larger tadpoles are usually pale yellow with scattered dark flecks or faint dorsal mottling. In preservative the red wash disappears and yellow fades to white, otherwise there is little change.

Comparison with other Colostethus tadpoles - In being exotrophic and arboreal, tadpoles of Colostethus beebei are readily distinguished from all other species of Colostethus from the Guiana Shield region. When compared to tadpoles of other Colostethus from the region, C. beebei differs from C. degranvillei and $C$. stepheni by the presence of a typical oral disc (tadpoles endotrophic and lacking keratinized and typical oral structures in C. degranvillei and C. stepheni (cf. Lescure 1984, Juncá et al. 1994); from C. parkerae in position of nares (naris-snout distance 2.0 times greater than eyenaris distance in $C$. beebei, 0.5 times in $C$. parkerae); from C. tamacuarensis, C. undulatus, and C. wothuja in oral disc not emarginate (emarginate in C. tamacuarensis, C. undulatus, and C. wothuja).

Vocalization - The majority of male $C$. beebei called antiphonally in a socially facilitated manner, with males responding to each other to produce duets, trios, and quartets in such a way that neighbors rarely overlap one another's calls (Figure 11). Quantitative measures of spectral and temporal parameters of the bird-like whistles of ten males exhibited low variation among individuals (mean $\pm 1 \mathrm{SD}$; range) for 
lower (4.64 $\pm 0.55 \mathrm{kHz}$; 3.94-5.28) and upper (4.72 $\pm 0.54 \mathrm{kHz} ; 4.04-5.35)$ frequencies, calls/ $\min (46.5 \pm 2.73 ; 44.0-51.0)$, notes/call (4.5 \pm $0.53 ; 4.0-5.0)$, intercall interval (1.60 \pm 0.58 sec; 0.96-2.72), and internote interval (39.52 \pm 5.96 ms; 33.48-52.30; Figure 11) (cf. also Bourne et al. 2001).

Natural history - Colostethus beebei is found exclusively in large terrestrial bromeliads (Brocchinia micrantha). Eggs are deposited on the leaves and the exotrophic tadpoles live in the water-retaining leaf axils (phytotelmata). Reproduction does not appear to be seasonally constrained. Courtship and late-stage tadpoles have been observed in March and from June through August (Bourne et al. 2001). Females collected in June and July contain 1-5 enlarged darkly pigmented eggs, $0.9-1.1 \mathrm{~mm}$ in diameter. Clutch size is typically four (Bourne et al. 2001). Tadpoles feed on detritus, insect larvae, unfertilized eggs and other tadpoles, both con- and heterospecific (Bourne et al. 2001). Hoff et al. (1999) list anuran species that have oophagous tadpoles; Colostethus beebei can be added to this list. Details of habitat, diet, vocalization, reproductive behavior, and parental care are in Bourne et al. (2001) and Kok et al. (2005), and details of predator avoidance and foraging behavior are in Bourne (2001).

Distribution - Colostethus beebei has been found only in an area of approximately 600 hectares on the Kaieteur plateau, at the eastern edge of the Pakaraima Mountains at an elevation of $450 \mathrm{~m}$ (Figure 9). The type locality of $C$. beebei has been described in detail by Bourne (2001), Bourne et al. (2001), and Kok et al. (2005). Although it is associated with the bromeliad Brocchinia micrantha at Kaieteur, it has not been reported in association with this bromeliad elsewhere (Bourne et al. 2001). However, much of the Pakaraima region remains unexplored, and the possibility exists that $C$. beebei may occur elsewhere in the area.

\section{Discussion}

Most cryptic dendrobatid species have been placed in the genus Colostethus although no clear synapomorphies unite them (Coloma 1995). Recent results of phylogenetic analyses have pointed out the paraphyly of Colostethus either based on molecular evidence (Vences et al. 2000, 2003, Santos et al. 2003) or morphological data (Kaplan 1997; Grant and Rodríguez 2001; Grant 2004). Because the new species cannot be placed in any other named clade of dendrobatids, it seems reasonable to assign it to this genus based on its close resemblance to Colostethus marchesianus.

The affinities of the new species are unknown. In lacking a median lingual process, Colostethus granti differs from most of the Guiana Shield nominal species and appears more closely related to some Amazonian Colostethus. Based on morphological characters (e.g. small size, reduced toe webbing, Finger III in male not swollen, Finger I longer than II) and coloration, the new species seems to be closely related to $C$. marchesianus and other similar species found in Brazilian Amazonia, but also to the recently described $C$. pittieri from northern Venezuela. The species groups of Rivero (“1988” [1990]), Rivero and Serna (“1988 [1989]) and Morales (“2000” [2002]) appear to be mostly artificial [see comments by Grant and Rodriguez (2001)] and of questionable taxonomic utility, so we do not consider it useful to place Colostethus granti in any of them. It should be noted that $C$. granti possibly corresponds to the "Colostethus sp. aff. marchesianus (A)" of Vences et al. (2003), but this is speculative because, as stated above, the material used by these authors was not available to us.

The affinities of Colostethus beebei also are unknown. The species has a median lingual process, as do most Guiana Shield Colostethus, although the evolutionary significance of this is not certain (Grant et al. 1997).

Lescure (1975) was the first to erroneously refer to Colostethus beebei outside Guyana in 
his description of Colosthetus [sic] degranvillei, but did not refer to any museum material. In his preliminary list of anurans of French Guiana, the same author reported the collection of Colostethus beebei in three localities in French Guiana (Lescure 1976). Unfortunately, a number of authors perpetuated the confusion by subsequently reporting $C$. beebei from French Guiana (e.g. Gasc 1986, Lescure 1987, Hoogmoed and Ávila-Pires 1991, Born 1996a, b, Boistel and de Massary 1999, Marty and Gaucher 1999, Kok 2000a, Lescure and Marty 2001, Born and Gaucher 2001a, b, Frost 2004), for some probably as a result of their examination of misidentified specimens at MNHN. Colostethus beebei was also reported from Surinam (Frost 2004). Examination of the type material and/or careful reading of Noble's description would have easily avoided this confusion. Although his description is brief, Noble is unambiguous in his description of $C$. beebei having "the first finger not as long as the second". In the misidentified taxon from French Guiana (now described as $C$. granti), the first finger is definitely longer than the second, as notably stated by Lescure and Marty (2001) who are therefore in conflict with the original description. Colostethus baeobatrachus was also mistaken for $C$. beebei by Born (1996a), and thus most probably also by Born (1996b), who presented a photograph of the species, which is undoubtedly C. baeobatrachus, and by Hoogmoed and Avila-Pires (1991), who offered a short description of the species that exactly matches that of $C$. baeobatrachus. Born and Gaucher (2001a, b) stated that C. baeobatrachus is absent from the Nouragues Nature Reserve and that C. "beebei" occurs throughout the forest. Because Colostethus granti is rather uncommon and found in small isolated populations at Arataye and Nouragues, we suspect that at least part of the C. "beebei" reported from Nouragues by these authors are in fact $C$. baeobatrachus. For the same reason, we believe that Gasc (1986), who mentioned C. "beebei" being one of the most abundant species at Arataye, also confused C. beebei with
C. baeobatrachus. Colostethus baeobatrachus was also reported as $C$. brunneus from French Guiana (Lescure 1976), and, at least on one occasion, as C. stepheni (Kok 2000b). Kok (2000a) reported a male C. "beebei", $19.9 \mathrm{~mm}$ SVL, carrying tadpoles. This specimen is now the holotype of Colostethus granti and its correct SVL is $14.9 \mathrm{~mm}$; this is one of the numerous printing errors in that article (regrettably proofs were not seen by author).

Another undescribed Colostethus species, superficially similar to Colostethus granti, occurs sympatrically in the Saül area and perhaps elsewhere. Therefore, the distribution map provided by Lescure and Marty (2001) may be erroneous, as they did not discriminate between the two similar taxa. The same authors mentioned no sexual dimorphism and characterized the species by a sulfur yellow belly ("Face ventrale jaune soufre”), which in fact occurs only in females.

Due to its relatively wide range and apparently healthy populations, we suggest that Colostethus granti be classified as "Least Concern" (LC) in accordance with the criteria of IUCN et al. (2004). Colostethus beebei has a very small geographic range, currently limited to a single known population in Kaieteur National Park, and a high degree of habitat specialization. Consequently, and due to impending development in the park, we strongly recommend that the species be removed from the LC category and classified as "Vulnerable" (VU) (IUCN et al. 2004) even if the population of C. beebei appears quite stable at present.

\section{Acknowledgements}

Specimens of Colostethus granti were collected and exported under Permit Numbers 98/198/AUT and arrêté 626 1D/1B/ENV du 07 Mai 1999 from the Ministère Français de l'Aménagement du Territoire et de l'Environnement and the Section Environnement de la Préfecture de la Région Guyane, respectively. Specimens of C. beebei were collected under Permit Numbers 
180604BR011 and 030605BR006 and exported under Permit Numbers 100804SP010 and 230605SP001 issued by the Guyana Environmental Protection Agency (EPA). The field assistance of P. Benjamin, F. Marco, R. Williams, H. Sambhu, and I. Roopsind (in Guyana) as well as those of D. Rignon, J. Tarin and the Couffignal family (in French Guiana) was greatly appreciated. We also thank I. Ramdass, R. Lilwah, and A. Bernard-Barry (EPA), D. Arjoon, P. Da Silva, K. Erskine, and C. Bernard of the University of Guyana (UG), and the Rahaman family of Menzies Landing, Guyana. Margaret and Malcolm Chan-A-Sue handled the logistics and coordinated travels to Kaieteur National Park. We are grateful to Jackie Van Goethem, Anne Franklin, and Yves Samyn (Belgian Focal Point to the Global Taxonomy Initiative, IRSNB) for enthusiastic support; J. Cillis (IRSNB) for technical assistance in SEM; S. Bruaux (IRSNB) for technical help in Brussels; J. Constant (IRSNB) for photographs of the extremities of $C$. granti; O. Tostain (Cabinet ECOBIOS, Cayenne) for use of his photograph of C. granti eggs; J. P. Caldwell of the Sam Noble Oklahoma Museum of Natural History, Oklahoma and A. P. Lima of Instituto Nacional de Pesquisas da Amazônia, Manaus for useful information regarding undescribed Colostethus species from Brazil; and to M. S. Hoogmoed (Museu Paraense Emiìlio Goeldi, Beleìm) for constructive discussions. For the loan or exchange of specimens under their care we thank A. Ohler (MNHN) and E. La Marca (Universidad de los Andes, Mérida). This study was funded by grants from the Belgian Directorate General for Development Cooperation to GRB, PJRK and GLL, and the Royal Ontario Museum Foundation to RDM. Fieldwork of PJRK in French Guiana was partly funded by the Systematics and Biochemical Taxonomy Section of IRSNB. This is contribution 329 of the Centre for Biodiversity and Conservation Biology, ROM and number 109 in the Smithsonian's Biological Diversity of the Guiana Shield Program publication series.

\section{References}

Altig, R. and G. F. Johnston. 1989. Guilds of anuran larvae: relationships among developmental modes, morphologies and habitats. Herpetological Monographs 3: 81-109.

Altig, R. and R. W. McDiarmid. 1999. Body plan. Pp. 2451 in R. W. McDiarmid and R. Altig (eds.), Tadpoles - the biology of anuran larvae. Chicago. University of Chicago Press.

Barrio-Amorós, C. L., O. Fuentes and G. Rivas. 2004. Two new species of Colostethus (Anura: Dendrobatidae) from the Venezuelan Guayana. Salamandra 40: 183-200.

Boistel, R. and J-C. de Massary. 1999. Les amphibiens vénéneux de la famille des dendrobatidés. Le Courrier de la Nature 176: 38.

Born, M. 1996a. Reptiles and Amphibians of Nouragues, French Guiana. Wageningen, The Netherlands. Marga Born and Wageningen Agricultural University, Department of Forestry. 55 pp.

Born, M. 1996b. Species diversity in a neotropical rain forest: amphibians of Nouragues, a nature reserve in French Guiana. Bos Nieuwsletter 15: 25-33.

Born, M. G. and P. Gaucher. 2001a. Distribution and life histories of amphibians and reptiles. Pp. 167-184 in F. Bongers, P. Charles-Dominique, P-M. Forget, and M. Théry (eds.), Nouragues: dynamics and plant-animal interactions in a neotropical rainforest (Chapter 15). Monographiae Biologicae 80. Dordrecht, The Netherlands. Kluwer Academic Publisher.

Born, M. G. and P. Gaucher. 2001b. Amphibian and reptile species at the Nouragues Nature Reserve. Pp. 371-379 in F. Bongers, P. Charles-Dominique, P-M. Forget, and M. Théry (eds.), Nouragues: dynamics and plant-animal interactions in a neotropical rainforest (Chapter 15). Monographiae Biologicae 80. Dordrecht, The Netherlands. Kluwer Academic Publisher.

Bourne, G. R. 2001. Color pattern, predator avoidance, and foraging behavior in the Golden Frog Colostethus beebei (Anura: Dendrobatidae). Herpetological Review 32: 225-228.

Bourne, G. R., A. C. Collins, A. M. Holder, and C. L. McCarthy. 2001. Vocal communication and reproductive behavior of the frog Colostethus beebei in Guyana. Journal of Herpetology 35: 272-281.

Caldwell, J. P. and A. P. Lima. 2003. A new Amazonian species of Colostethus with a nidicolous tadpole. Herpetologica 59: 218-233.

Caldwell, J. P., A. P. Lima and C. Keller. 2002. Redescription of Colostethus marchesianus (Melin, 1941) from its type locality. Copeia 2002: 157-165.

Charif, R. A., S. Mitchell and C. W. Clarke. 1996. Canary 1.2 User's Manual. Ithaca, NY. Cornell Laboratory of Ornithology. 
Cochran, D. M. “1954” [1955]. Frogs of southeastern Brazil. Bulletin of the United States National Museum 206: 1-423.

Cochran, D. M. and C. J. Goin. 1970. Frogs of Colombia. Bulletin of the United States National Museum 288: 1-655.

Coloma, L. A. 1995. Ecuadorian frogs of the genus Colostethus (Anura: Dendrobatidae). University of Kansas Museum of Natural History Miscellaneous Publications 87: 1-72.

Cope, E. D. 1887. Synopsis of the batrachia and reptilia obtained by H. H. Smith in the Province of Mato Grosso, Brazil. Proceedings of the American Philosophical Society 24: 44-60.

Duellman, W. E. and L. Trueb. 1986. Biology of Amphibians. McGraw-Hill Book Co., New York. 670 pp.

Echeverría, D. D. 1997. Microanatomy of the buccal apparatus and oral cavity of Hyla minuta Peters, 1872 larvae (Anura, Hylidae), with data on feedings habits. Alytes 15: 26-36.

Edwards, S. R. 1971. Taxonomic notes on South American Colostethus with descriptions of two new species (Amphibia, Dendrobatidae). Proceedings of the Biological Society of Washington 84: 147-162.

Edwards, S. R. 1974. Taxonomic notes on South American dendrobatid frogs of the genus Colostethus. Occasional Papers of the Museum of Natural History 30: 114.

Frost, D. R. 2004. Amphibian Species of the World: an Online Reference. URL: http://research.amnh.org/ herpetology/amphibia/index.html. Captured on 1 August 2005.

Gasc, J-P. 1986. Le peuplement herpétologique d'Astrocaryum paramaca (Arecacées), un palmier important dans la structure de la forêt en Guyane française. Mémoires du Muséum national d'Histoire naturelle de Paris. Série A. Zoologie 132: 97-107.

Gosner, K. L. 1960. A simplified table for staging anuran embryos and larvae with notes on identification. Herpetologica 16: 183-190.

Grant, T. 2004. On the identities of Colostethus inguinalis (Cope, 1868) and C. panamensis (Dunn, 1933), with comments on C. latinasus (Cope, 1863) (Anura: Dendrobatidae). American Museum Novitates 3444: $1-24$.

Grant, T. and F. Castro. 1998. The cloud forest Colostethus (Anura, Dendrobatidae) of a region of the Cordillera Occidental of Colombia. Journal of Herpetology 32: 378-392.

Grant, T. and L. O. Rodríguez. 2001. Two new species of frogs of the genus Colostethus (Dendrobatidae) from Peru and a redescription of $C$. trilineatus (Boulenger, 1883). American Museum Novitates 3355: 1-24.
Grant, T., E. C. Humphrey and C. W. Myers. 1997. The median lingual process of frogs: a bizarre character of Old World ranoids discovered in South American dendrobatids. American Museum Novitates 3212: 1-40.

Hayek, L. A., W. R. Heyer and C. Gascon. 2001. Frog morphometrics: a cautionary tale. Alytes 18: 153-177.

Hoff, K., A. Blaustein, R. W. McDiarmid, and R. Altig. 1999. Behavior: Interactions and their consequences. Pp. 215-239 in McDiarmid, R. W. and R. Altig (eds.), Tadpoles: the Biology of Anuran Larvae. Chicago. University of Chicago Press.

Hoogmoed, M. S. and T. C. S. Ávila-Pires. 1991. Annotated Checklist of the Herpetofauna of Petit Saut, Sinnamary River, French Guiana. Zoologische Mededelingen 65: 53-88.

Huber, O. and M. N. Foster (eds). 2003. Conservation Priorities for the Guayana [sic] Shield: 2002 Consensus. Washington. Conservation International, Center for Applied Biodiversity Science. 97 pp.

IUCN, Conservation International, and NatureServe. 2004. Global Amphibian Assessment. URL: http:// www.globalamphibians.org. Captured on 1 August 2005.

Jiménez de la Espada, M. 1871. Faunae neotropicalis species quaedam nondum cognitae. Jornal de Sciencias Mathematicas Physicas e Naturaes Tomo III: 5765.

Juncá, F. A., R. Altig and C. Gascon. 1994. Breeding biology of Colostethus stepheni, a dendrobatid frog with a nontransported nidicolous tadpole. Copeia 1994: 747-750.

Kaplan, M. 1997. A new species of Colostethus from the Sierra Nevada de Santa Marta (Colombia) with comments on intergeneric relationships within the Dendrobatidae. Journal of Herpetology 31: 369-375.

Kok, P. J. R. 2000a. A survey of the anuran fauna of Montagne Belvédère, county of Saül, French Guiana: field list with comments on taxonomy and ecology. The British Herpetological Society Bulletin 71: 6-26.

Kok, P. J. R. 2000b. Addenda to "A survey of the anuran fauna of Montagne Belvédère, county of Saül, French Guiana”. The Herpetological Bulletin 73: 1.

Kok, P. J. R., G. R. Bourne, D. Arjoon, N. M. Wulff and G. L. Lenglet. 2005. Colostethus beebei. Charismatic Jewel of the Lost World: The Golden Rocket Frog. Reptilia 38: 47-53.

La Marca, E. “1996” [1997]. Ranas del género Colostethus (Amphibia: Anura: Dendrobatidae) de la Guyana Venezolana con la descripción de siete especies nuevas. Publicaciones de la Asociación de Amigos de Doñana 9: 1-64.

La Marca, E. 2004. Systematic status of an enigmatic and possibly endangered dendrobatid frog (Colostethus 
dunni) from the valley of Caracas, northern Venezuela. Herpetotropicos 1: 19-28.

La Marca, E., M. Vences and S. Lötters. 2002. Rediscovery and mitochondrial relationships of the dendrobatid frog Colostethus humilis suggest parallel colonization of the Venezuelan Andes by poison frogs. Studies on Neotropical Fauna and Environment 37: 233-240.

La Marca, E., J. Manzanilla and A. Mijares-Urrutia. 2004. Revisión taxonómica del Colostethus del norte de Venezuela confundido durante largo tiempo con $C$. brunneus. Herpetotropicos 1: 40-50.

Lannoo, M. J., D. S. Townsend and R. J. Wassersug. 1987. Larval life in the leaves: arboreal tadpole types, with special attention to the morphology, ecology and behaviour of the oophagous Osteopilus brunneus (Hylidae) larva. Fieldiana Zoology 38: 1-31.

Lescure, J. 1975. Contribution à l'étude des Amphibiens de Guyane française - III. Une nouvelle espèce de Colosthetus [sic] (Dendrobatidae): Colosthetus [sic] degranvillei. Bulletin du Muséum national d'Histoire naturelle, Paris, 3e Série, Zoologie 203: 413-420.

Lescure, J. 1976. Contribution à l’étude des amphibiens de Guyane française. VI. Liste préliminaire des anoures. Bulletin du Muséum national d'Histoire Naturelle de Paris (3) 265: 475-525.

Lescure, J. 1984. Las larvas de dendrobatidae [sic]. Reunión Iberoamericana de Conservación y Zoología de Vertebrados. Actas II: 37-47.

Lescure, J. 1987. Les Amphibiens anoures de la forêt guyanaise (région de Trois-Sauts, Guyane française). Mémoires du Muséum national d'Histoire naturelle de Paris, Série A, Zoologie 132: 43-52.

Lescure, J. and C. Marty. 2001. Atlas des Amphibiens de Guyane. SPN/MNHN, Paris, Patrimoines naturels 45: 1-388.

Lima, A. P. and J. P. Caldwell. 2001. A new Amazonian species of Colostethus with sky blue digits. Herpetologica 57: 180-189.

Lips, K. R., P. A. Burrowes, J. R. Mendelson III, and G. Parra-Olea. 2005. Amphibian declines in Latin America: widespread population declines, extinctions, and impacts. Biotropica 37: 163-165.

Martins, M. 1989. Nova espécie de Colostethus da Amazônia central (Amphibia: Dendrobatidae). Revista Brasileira de Biologia 49: 1009-1012.

Marty, C. and P. Gaucher. 1999. Guide sonore des Amphibiens Anoures de Guyane. Guides sonores du Monde, CEBA, France.

Meinhardt, D. J. and J. R. Parmelee. 1996. A new species of Colostethus (Anura: Dendrobatidae) from Venezuela. Herpetologica 52: 70-77.

Melin, D. 1941. Contributions to the knowledge of the
Amphibia of South America. Göteborgs Kungliga Vetenskaps och Vitter-Hets Samhalles Handlingar, Ser. B 1: 1-71.

Morales, V. R. 1994. Taxonomía sobre algunos Colostethus (Anura: Dendrobatidae) de Sudamérica, con descripción de dos especies nuevas. Revista Española de Herpetología 8: 95-103.

Morales, V. R. “2000” [2002]. Sistemática y Biogeografía del grupo trilineatus (Amphibia, Anura, Dendrobatidae, Colostethus), con descripción de once especies nuevas. Publicaciones de la Asociación de Amigos de Doñana 13: 1-59.

Myers, C. W. and W. E. Duellman. 1982. A new species of Hyla from Cerro Colorado, and other tree frog records and geographical notes from western Panama. American Museum Novitates 2752: 1-32.

Myers, C. W. and M. A. Donnelly. 1997. A tepui herpetofauna on a granitic mountain (Tamacuari) in the borderland between Venezuela and Brazil. Report of the Phipps-Tapirapecó Expedition. American Museum Novitates 3213: 1-71.

Myers, C. W. and M. A. Donnelly. 2001. Herpetofauna of the Yutajé-Corocoro massif, Venezuela: second report from the Robert G. Goelet American Museum Terramar expedition to the northwestern tepuis. Bulletin of the American Museum of Natural History 261: 1-85.

Myers, C. W., A. Paolillo and J. W. Daly. 1991. Discovery of a defensively malodorous and nocturnal frog in the family Dendrobatidae: phylogenetic significance of a new genus and species from the Venezuelan Andes. American Museum Novitates 3002: 1-33.

Noble, G. K. 1923. New batrachians from the Tropical Research Station British Guiana. Zoologica 3: 288-305.

Orton, G. L. 1953. The systematics of vertebrate larvae. Systematic Zoology 2: 63-75.

Rivero, J. A. 1961. Salientia of Venezuela. Bulletin of the Museum of Comparative Zoology 126: 1-267.

Rivero, J. A. “1988” [1990]. Sobre las relaciones de las especies del género Colostethus (Amphibia, Dendrobatidae). Memoria de la Sociedad de Ciencias Naturales La Salle 48: 3-32.

Rivero, J. A. and M. A. Serna. “1988” [1989]. La identificación de los Colostethus (Amphibia, Dendrobatidae) de Colombia. Caribbean Journal of Science 24: 137-154.

Rivero, J. A., J. A. Langone and C. M. Prigioni. 1986. Anfibios colectados por la expedición del Museo Nacional de Historia Natural de Montevideo al Río Caura, Estado Bolivar, Venezuela; con la descripción de una nueva especie de Colostethus (Dendrobatidae). Comunicaciones Zoologicas del Museo de Historia Natural de Montevideo 11: 1-15.

Santos, J. C., L. A. Coloma and D. C. Cannatella. 2003. 
Multiple, recurring origins of aposematism and diet specialization in poison frogs. Proceedings of the National Academy of Science of the United States of America 100: 12792-12797.

Savage, J. M. and W. R. Heyer. 1967. Variation and distribution of the tree-frog genus Phyllomedusa in Costa Rica, Central America. Beiträge zur Neotropischen Fauna 5: 111-131.

Savage, J. M. and W. R. Heyer. 1997. Digital webbing formulae for anurans: a refinement. Herpetological Review 28: 131

Veiga-Menoncello A. C., A. P. Lima and S. M. ReccoPimentel. 2003. Cytogenetic analysis of four central Amazonian species of Colostethus (Anura - Dendrobatidae) with a diploid complement of 22 chromosomes. Hereditas 139: 189-198.

Vences, M., J. Kosuch, S. Lötters, A. Widmer, K-H. Jungfer, J. Köhler, and M. Veith. 2000. Phylogeny and classification of Poison Frogs (Amphibia: Dendrobatidae), based on mitochondrial $16 \mathrm{~S}$ and $12 \mathrm{~S}$ riboso- mal RNA gene sequences. Molecular Phylogenetics and Evolution 15: 34-40.

Vences, M., J. Kosuch, R. Boistel, C. F. B. Haddad, E. La Marca, S. Lötters, and M. Veith. 2003. Convergent evolution of aposematic coloration in Neotropical poison frogs: a molecular phylogenetic perspective. Organisms Diversity and Evolution 3: 215-226.

Wilkinson, L. 1997. SYSTAT 7.0. Statistics. Chicago, Illinois. SPSS Inc.

Young, B. E., K. R. Lips, J. K. Reaser, R. Ibáñez, A. W. Salas, J. R. Cedeño, L. A. Coloma, S. Ron, E. La Marca, J. R. Meyer, A. Muñoz, F. Bolaños, G. Chaves, and D. Romo. 2001. Population declines and priorities for amphibian conservation in Latin America. Conservation Biology 15: 1213-1223.

Young, B. E., S. N. Stuart, J. S. Chanson, N. A. Cox, and T. M. Boucher. 2004. Disappearing Jewels: The Status of New World Amphibians. Arlington, Virginia. NatureServe. 54 pp.

\section{Appendix I: Additional Specimens Examined}

Colostethus baeobatrachus - FRENCH GUIANA: Régina: Pic Matécho $\left(03^{\circ} 45^{\prime} \mathrm{N}\right.$, 53⒉' W, elevation $400 \mathrm{~m}$ ), IRSNB 13001 (2 specimens), IRSNB 13011, IRSNB 13015 (4 specimens), IRSNB 13018 (3 specimens). Roura: Cacao $\left(04^{\circ} 34^{\prime} \mathrm{N}, 52^{\circ} 28^{\prime} \mathrm{W}\right)$, not far from the village, IRSNB 12662; Crique Bagot, IRSNB 12663; Crique Bagot, Dégrad Kwata, IRSNB 12767-68, IRSNB 12975. Saül: Saül, Montagne Belvédère $\left(03^{\circ} 37^{\prime} \mathrm{N}, 53^{\circ} 10^{\prime} \mathrm{W}\right.$, elevation $c a .250 \mathrm{~m}), c a .7 \mathrm{~km}$ SE from the village, IRSNB 12753-55, IRSNB 12970, IRSNB 12976-79.

Colostethus beebei - GUYANA: Potaro Siparuni: Kaieteur National Park, Kaieteur plateau $\left(05^{\circ} 10^{\prime} \mathrm{N}, 59^{\circ} 29^{\prime} \mathrm{W}\right.$, elevation $\left.450 \mathrm{~m}\right)$, IRSNB 13721-26, 13728-53, ULABG 6817 (ex IRSNB 13727), ROM 43178-97; IRSNB 13754 (tadpoles), ROM 42994 (tadpoles).

Colostethus degranvillei - FRENCH GUIANA: Roura: Cacao (043ㄴ $\mathrm{N}, 52^{\circ} 28^{\prime} \mathrm{W}$ ), not far from the village, IRSNB 12683; Crique Ste Anne IRSNB 12684, IRSNB 12769 (4 specimens). Saül: Saül, Montagne Belvédère (03³7'
N, 5310' W, elevation ca. $250 \mathrm{~m}$ ), ca. 7 km SE from the village, IRSNB 12950-12953. Régina: Pic Matécho (0345' N, 53²9' W, elevation 400 m), IRSNB 13000 (13 specimens).

Colostethus granti - FRENCH GUIANA: Maripasoula: Haut Marwani $\left(02^{\circ} 36^{\prime} \mathrm{N}, 5^{\circ} 01^{\prime}\right.$ W, elevation $159 \mathrm{~m})$, MNHN 2005.0269-71; Maripasoula, Haute Wanapi $\left(02^{\circ} 30^{\prime} \mathrm{N}, 53^{\circ} 49^{\prime}\right.$ W, elevation $192 \mathrm{~m}$ ), MNHN 2005.0268. Papaïchton: Montagne Kotika (elevation 700 m), MNHN 2005.0272-74; MNHN 2005.027677 (tadpoles). Saül: Saül, Montagne Belvédère ( $3^{\circ} 37^{\prime} \mathrm{N}, 5^{\circ} 10^{\prime} \mathrm{W}$, elevation ca. $250 \mathrm{~m}$ ), ca. 7 $\mathrm{km}$ SE from the village, IRSNB 1932 (holotype), IRSNB 1933, IRSNB 1935-36, ULABG 6816 (ex-IRSNB 1937); Saül, along the trail between the airstrip and the village, IRSNB 1934; Saül, Chemin des Gros Arbres, MNHN 2005.0275. St-Georges: Piton Armontabo (elevation $150 \mathrm{~m}$ ), Layon Est, MNHN 2005. 0266-67.

Colostethus pittieri - VENEZUELA: Estado Aragua: La Trilla (elevation 170 m), IRSNB 1931 (ex-ULABG 3959), ULABG 3955 (paratypes). 